This report tias been-prepared

for information and record.

purposes and is not to-be-referenced

in any publication.

NATIONAL BUREAU OF STANDARDS REPORT

10534

STUDY ON SMOKE AND GASES GENERATED FROM FIRES

AND

FIELD FIRE EXPERIMENTS FOR INTERIOR FINISH MATERIALS

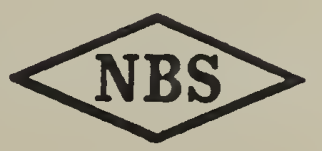

U.S. DEPARTMENT OF COMMERCE

NATIONAL BUREAU OF STANDARDS 


\section{NATIONAL BUREAU OF STANDARDS}

The National Bureau of Standards ' was established by an act of Congress March 3, 1901. Today, in addition to serving as the Nation's central measurement laboratory, the Bureau is a principal focal point in the Federal Government for assuring maximum application of the physical and engineering sciences to the advancement of technology in industry and commerce. To this end the Bureau conducts research and provides central national services in four broad program areas. These are: (1) basic measurements and standards, (2) materials measurements and standards. (3) technological measurements and standards, and (4) transfer of technology.

The Bureau comprises the Institute for Basic Standards, the Institute for Materials Research, the Institute for Applied Technology, the Center for Radiation Research, the Center for Computer Sciences and Technology, and the Office for Information Programs.

THE INSTITUTE FOR BASIC STANDARDS provides the central basis within the United States of a complete and consistent system of physical measurement; coordinates that system with measurement systems of other nations; and furnishes essential services leading to accurate and uniform physical measurements throughout the Nation's scientific community, industry, and commerce. The Institute consists of an Office of Measurement Services and the following technical divisions:

Applied Mathematics-Electricity-Metrology-Mechanics-Heat-Atomic and Molecular Physics-Radio Physics "-Radio Engineering "-Time and Frequency"-Astrophysics "-Cryogenics."

THE INSTITUTE FOR MATERIALS RESEARCH conducts materials research leading to improved methods of measurement standards, and data on the properties of well-characterized materials needed by industry, commerce, educational institutions, and Government; develops, produces, and distributes standard reference materials; relates the physical and chemical properties of materials to their behavior and their interaction with their environments; and provides advisory and research services to other Government agencies. The Institute consists of an Office of Standard Reference Materials and the following divisions:

Analytical Chemistry-Polymers-Metallurgy_Inorganic Materials-Physical Chemistry. THE INSTITUTE FOR APPLIED TECHNOLOGY provides technical services to promote the use of available technology and to facilitate technological innovation in industry and Government; cooperates with public and private organizations in the development of technological standards, and test methodologies; and provides advisory and research services for Federal, state, and local government agencies. The Institute consists of the following technical divisions and offices:

Engineering Standards-Weights and Measures - Invention and Innovation - Vehicle Systems Research-Product Evaluation--Building Research-Instrument Shops-Measurement Engineering-Electronic Technology-Technical Analysis.

THE CENTER FOR RADIATION RESEARCH engages in research, measurement, and application of radiation to the solution of Bureau mission problems and the problems of other agencies and institutions. The Center consists of the following divisions:

Reactor Radiation-Linac Radiation-Nuclear Radiation-Applied Radiation.

THE CENTER FOR COMPUTER SCIENCES AND TECHNOLOGY conducts research and provides technical services designed to aid Government agencies in the selection, acquisition, and effective use of automatic data processing equipment; and serves as the principal focus for the development of Federal standards for automatic data processing equipment, techniques, and computer languages. The Center consists of the following offices and divisions:

Information Processing Standards-Computer Information - Computer Services - Systems Development-Information Processing Technology.

THE OFFICE FOR INFORMATION PROGRAMS promotes optimum dissemination and accessibility of scientific information generated within NBS and other agencies of the Federal government; promotes the development of the National Standard Reference Data System and a system of information analysis centers dealing with the broader aspects of the National Measurement System, and provides appropriate services to ensure that the NBS staff has optimum accessibility to the scientific information of the world. The Office consists of the following organizational units:

Office of Standard Reference Data-Clearinghouse for Federal Scientific and Technical Information "-Office of Technical Information and Publications-Library-Office of Public Information-Office of International Relations.

\footnotetext{
Headquarters and Laboratories at Gaithershurg. Maryland, unless otherwise noted: mailing address Washington, D.C. 20234. " Located at Boulder, Colorado 80302.

" Located at 5285 Port Royal Road, Springfield, Virginia 22151.
} 


\section{NATIONAL BUREAU OF STANDARDS REPORT NBS PROJECT \\ NBS REPORT \\ 4212229 \\ February 1, 1971 \\ 10534}

STUDY ON SMOKE AND GASES GENERATED FROM FIRES

by $F$. Saito and T. Wakamatsu

FIELD FIRE EXPERIMENTS FOR INTERIOR FINISH MATERIALS

by F. Saito

Building Research Institute, Tokyo

Translation

by

J. B. Fang

Fire Research Section

Building Research Division, NBS

of

Selected Portions of Articles Published

in

Industrial Materials Vol. 16, No. 13

and

Special Report of Building Research Institute of Japan

IMPORTANT NOTICE

NATIONAL BUREAU OF STAN for use within the Government. Be and review. For this reason, the pI whole or in part, is not authorizes Bureau of Standards, Washington, the Report has been specitically pre
Approved for public release by the director of the National Institute of Standards and Technology (NIST) on October 9, 2015 accounting documents intended jected to additional evaluation iting of this Report, either in iffice of the Director, National re Government agency for which es for its own use.

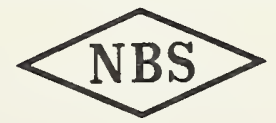

U.S. DEPARTMENT OF COMMERCE

NATIONAL BUREAU OF STANDARDS 

STUDY ON SMOKE AND GASES GENERATED FROM FIRES

by

F. Saito and T. Wakamatsu

and

FIELD FIRE EXPERIMENTS FOR INTERIOR FINISH MATERIALS

by

F. Saito

Translation by

J. B. Fang

\section{PREFACE}

This report is a translation of papers prepared by $F$. Saito and $T$. Wakamatsu describing research performed at the Building Research Institute of Japan.

The translation has been prepared to disseminate usefui information to interested fire research personnel on a needto-know basis and is not original work generated at the Building Research Division.

We express our appreciation to the authors for providing their original manuscript for translation and for their assistance in making this information available. 



\title{
STUDY ON SMOKE AND GASES GENERATED FROM FIRES
}

Investigation of the Effect of Ventilation Openings in a Compartment on Smoke Generation and Smoke Movement

\subsection{OPENING CONDITIONS OF FIRE ROOM AND SMOKE GENERATION}

\author{
by \\ F. Saito
}

In spite of using the same internal linings, the smoke generation from compartment fires will be different if opening conditions are not the same. Since the temperature and the burning rate in a fire room depend upon ventilation conditions, the rate of smoke generation should be considered along with the course of fire growth. Suppose a fire breaks out and ignites the wall materials first and then the ceiling to reach flashover. In this case, the rate of smoke production from room fires at time $t$ can be expressed in terms of internal lining areas of wall materials, $A_{1}, A_{2}$, etc., at the corresponding temperatures of $\mathrm{T}_{1}, \mathrm{~T}_{2}$, etc。, as

$$
\frac{d c}{d t}=\frac{d c_{1}}{d t} A_{1}+\frac{d c_{2}}{d t} A_{2}+\text { etc. }
$$

Most materials have such smoke characteristics that the maximum smoke generation occurs at about 400 to $500^{\circ} \mathrm{C}$. A small amount of smoke is produced at the initial stage of room fires since at such low room temperatures the burning area and the burning rate are small in spite of high rate of smoke generation per unit area. However, the amount of smoke generation increases rapidly at or after flashover because the area of active burning enlarges to cover the whole fire room through a steep rise in the room temperature. Consequently, the former commonly can be ignored campared to the latter.

In order to measure the quantity of smoke discharged from the fire room, it requires to determine the flow rate of hot gases leaving the opening and the history of smoke concentration.

Smoke generation from a fire room as described before has a close relation with flashover. A model box as shown in Figure 1 was used to simplify the geometry of a compartment and the smoke was gathered and measured at a hood hanging over the box. 


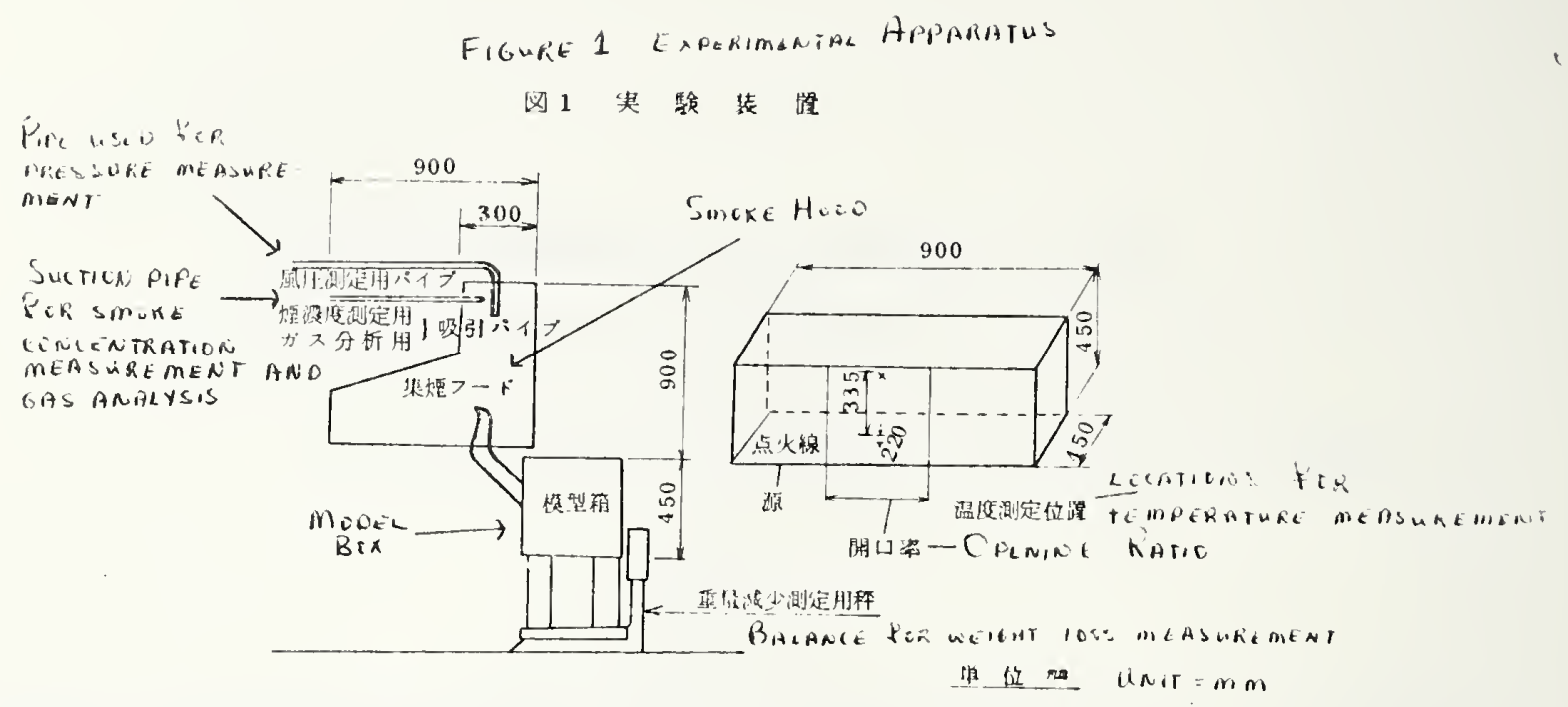

The rate of smoke generation is given by

$$
\frac{d c}{d t}=C_{s} v
$$

The total amount of smoke production thus can be expressed as

$$
C=\int_{0}^{t} C_{s} A v d t
$$

where $\mathrm{C}_{\mathrm{S}}$ is the light attenuation coefficient of smoke in $\mathrm{m}^{-1}$, $\mathrm{A}$ is the cross-sectional area of the hood in $\mathrm{m}^{2}, \mathrm{v}$ is the mean velocity of hot gases in $\mathrm{M} / \mathrm{sec}$ 。

The volume of the discharged gases in which the smoke particles are dispersed is considered here regardless of the concentration of smoke particles, and this volume is dependent on chemical composition of the material involved.

If $\mathrm{W} \mathrm{Kg}$ of wood-like material is burned in $\alpha$ percent of excess air, the volume of smoke produced has the following form:

$$
V=(0.72+3.97 \alpha) W
$$

and the rate of smoke generation after flashover can be written in terms of the burning rate $R$ as

$$
\frac{\mathrm{dc}}{\mathrm{dt}}=(0.72+3.97 \alpha) \mathrm{R}
$$




\section{Experimental}

The amount of smoke produced from compartment fires depends upon the amount of fire load, types of interior finish materials, size of the compartment (available internal lining area) and the rate of burning (the ventilation conditions).

According to the studies made by Kawagoe and Sekine, and Thomas, an approximate value for the burning rate of a fully developed fire can be obtained from the area $A\left(\mathrm{~m}^{2}\right)$ and the height $\mathrm{H}(\mathrm{m})$ of a ventilation opening through the equation: $R=5.5 \mathrm{~A} / \mathrm{H}$. In similar way, the present model experiment was constructed to determine the rate of burning, the smoke generating coefficient and the rate of smoke generation for various geometries of the openings. Three different sizes of model boxes of $1 \mathrm{~m} \times 2 \mathrm{~m} \times 1 \mathrm{~m}$ (H) (large scale), $0.5 \mathrm{~m} \times$ $1.0 \times 0.5 \mathrm{~m}(\mathrm{H})$ (medium scale) and $0.5 \mathrm{~m} \times 0.5 \mathrm{~m} \times 1.0 \mathrm{~m}$ (small scale model) were used, and the interior finish materials employed mainly were plywood in the present study.

\section{(a) Fire Source}

There is a certain relation among flashover, e.g. the flashover time (FOT), size of the fire source and the ratio of the combustible lining area (As) to the surface area of wood crib exposed to air $\left(A_{C}\right)$. (See Table 1 ) Latticetype wood cribs which were constructed from spruce sticks of $2 \mathrm{~cm} x 2 \mathrm{~cm}$ in cross-section by either $25 \mathrm{~cm}$ (large scale) or $12 \mathrm{~cm}$ (small scale) in length, and piled up 5 layers (total 30 pieces) for large scale or 4 layers (total 12 pieces) for small scale were used as fire sources. The cribs were ignited from the bottom row by a stick dipped in alcohol.

范1. 模型の大意さと火源

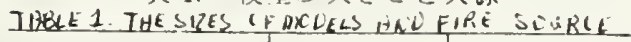

\begin{tabular}{|c|c|c|}
\hline - & As $\left(\mathrm{m}^{2}\right)$ & $A_{s} / A C$ \\
\hline 大 & $19 \sim 6.7$ & $10.6 \sim 20.4$ \\
\hline 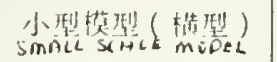 & 1.56 & $15.2 \sim 17.3$ \\
\hline 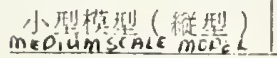 & 2.06 & $17.1 \sim 19.3$ \\
\hline
\end{tabular}

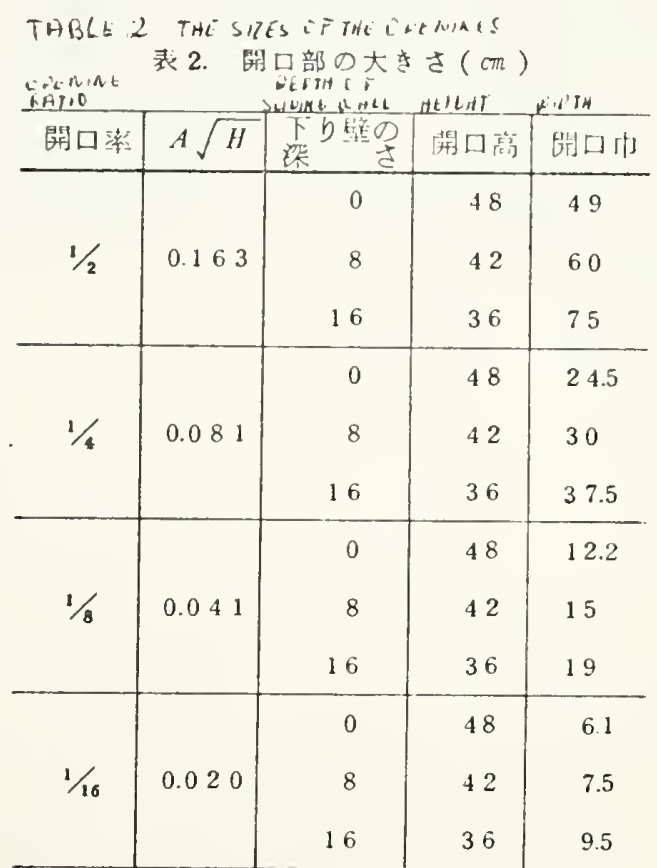




\section{(b) Ventilation Opening}

Various opening ratios which is defined as the ratio of the opening area to total area of the front wall, can be obtained by varying the width of the opening with a constant height. The opening ratio in the present study respectively were $1 / 3,1 / 4$, and $1 / 8$ for large scale and $1 / 2,1 / 4,1 / 8$, and $1 / 16$ for small scale models. (See Table 2)

\section{Discussion of Experimental Results}

The rate of smoke generation from a material depends on the product of the smoke generating coefficient and the burning rate. For a given opening condition, the rate of smoke production similar to the average temperature in a fire room can be expected to reach a certain value at flashover. However, from general observation, the internal materials were not burned with a constant rate in horizontal direction into their thickness, but part of them fell out and burned locally. These phenomena present some difficulties in determining the correct value among the measured ones.

\section{(i) Burning rate}

Figures 2 and 3 show typical weight loss curves. As indicated in the figures, these curves deviate noticeably from the linearity after flashover because of intermittent falling out of the internal lining materials. From the figures, the rate of burning was determined from the slope between two points in which the burning was at a steady state. The rate of burning is decreased with decreasing the opening ratio since the amount of air inflow is depressed. Yet, this burning rate is not further increased and shows almost constant when the opening ratio exceeds a certain region. Figure 4 indicates such relations. The dash lines in Figure 4 are the results reported by D. Gross on the burning velocity of cribs made from cellulose-base fiberboards. Under the same opening condition, the present work shows higher rate of burning. This is attributed to the differences in materials (plywood and fiberboard), and in stick geometry. 

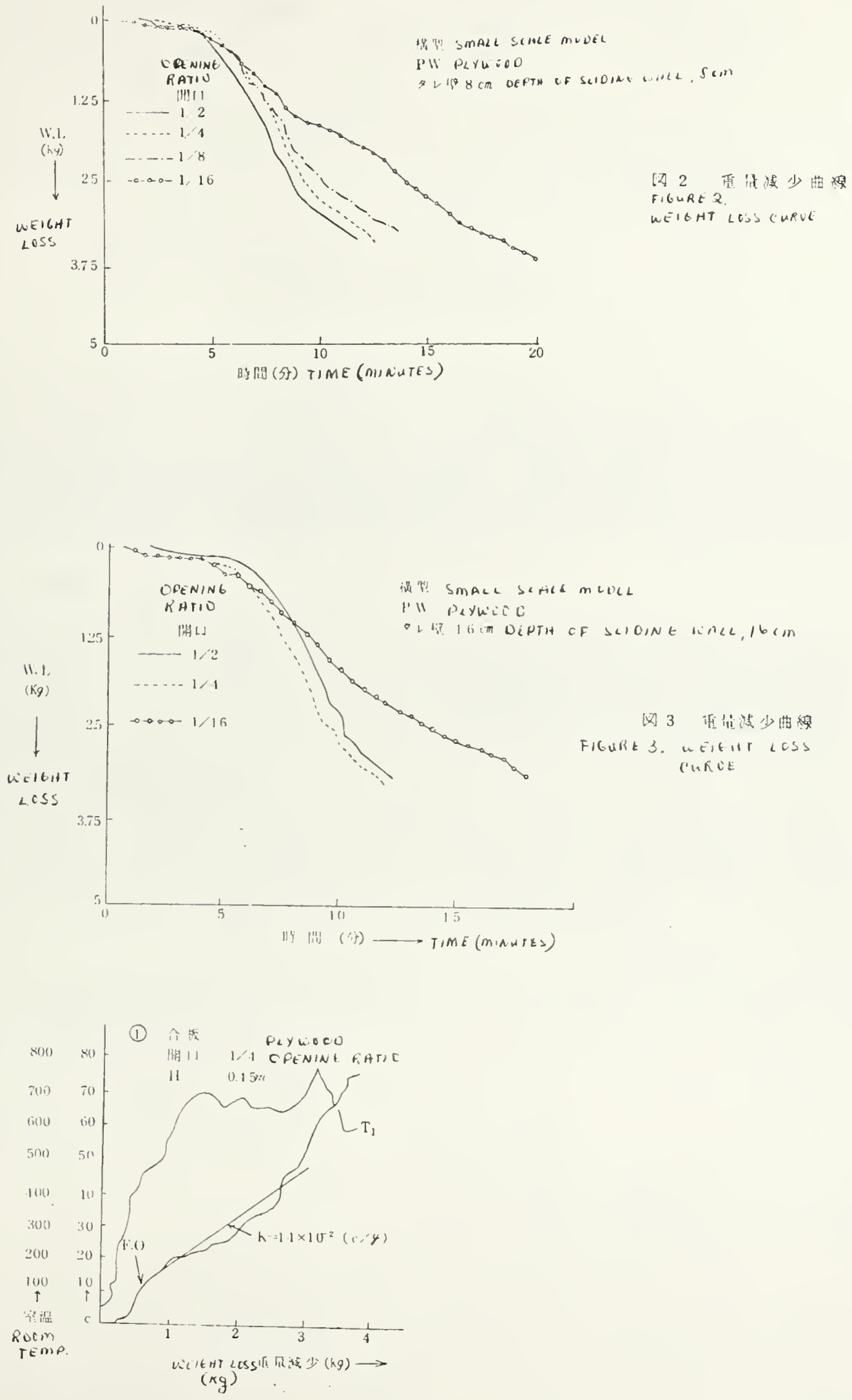


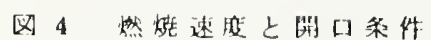
FIGUREA. THE BURRIRG KATE AND THE OPENINE CSNOITIONS

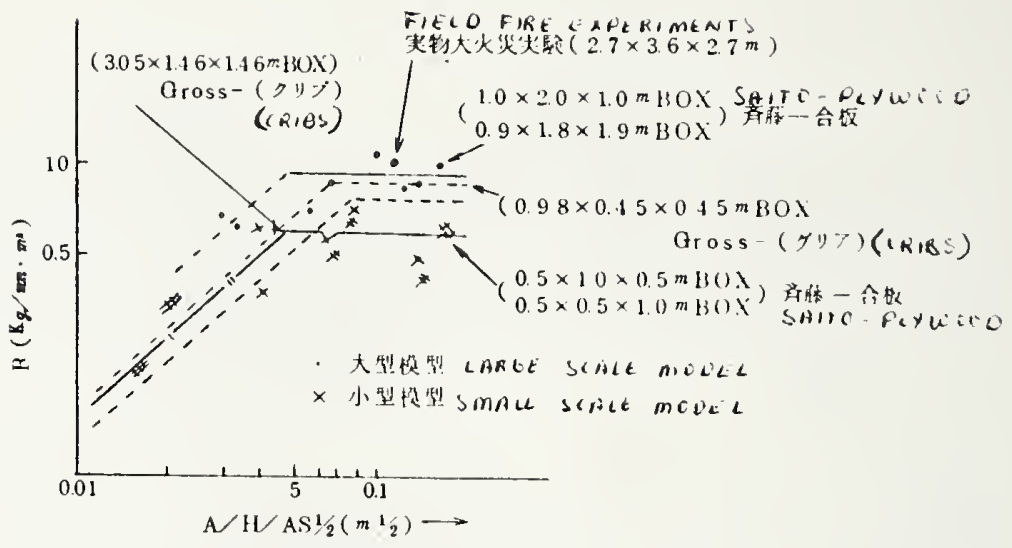

\section{(ii) Smoke Generating Coefficient}

Smoke generating coefficient $\mathrm{K}$ is defined as the amount of smoke generated per unit weight of the fuel consumed and can be estimated from the slope of weight 1 oss versus total amount of smoke production curve. Figure 5 shows a typical example.
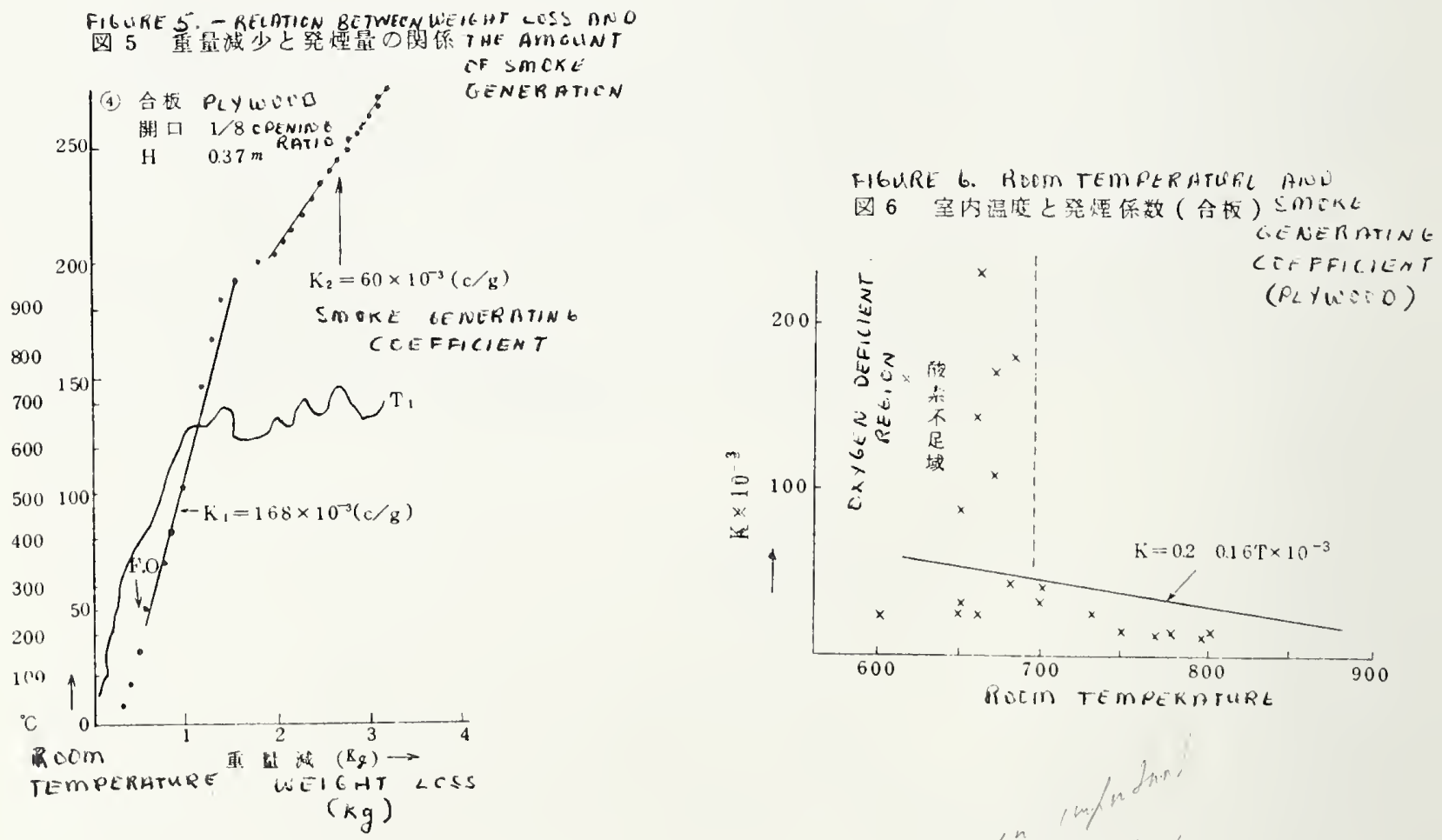


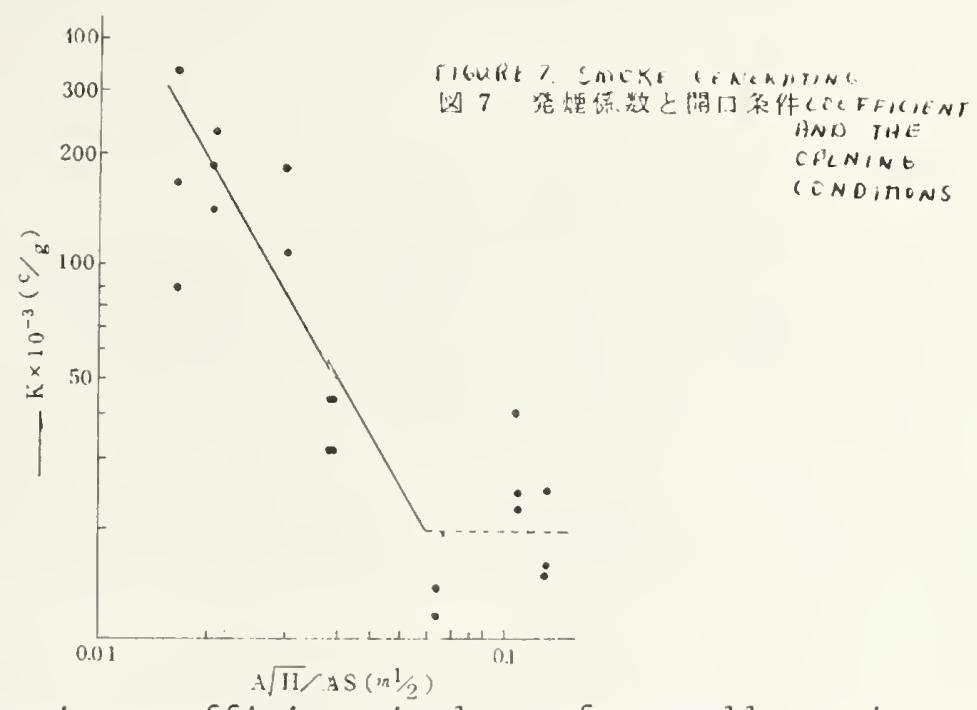

The smoke generating coefficient is large for small opening and decreases with an increase in the opening ratio. Figure 6 presents a relationship between the room temperature and the smoke generating coefficient. As shown in Figure 7 , at the value of $\mathrm{A} / \mathrm{H} / \mathrm{A}$ smaller than about 0.04 , the smoke generating coefficient increases rapidly because of the smoldering burning caused by the shortage of oxygen。

\section{(iii) Rate of Smoke Generation}

The rate of smoke production is determined by the product of burning rate and the smoke generating coefficient of the material, and as discussed before the opening condition is then an important controlling factor. Figures 4 and 7 indicate a relation that the smoke generating coefficient is inversely proportional to the rate of burning.

As shown in Figure 8, the rate of smoke generation decreases with an increase in the ventilation opening and tends to converge to a certain value. In the same figure, there is an estimated value which is calculated from the results of field experiment along with the consideration of friction effect due to a $30 \mathrm{~m}$ long passage between fire room and air entrance.
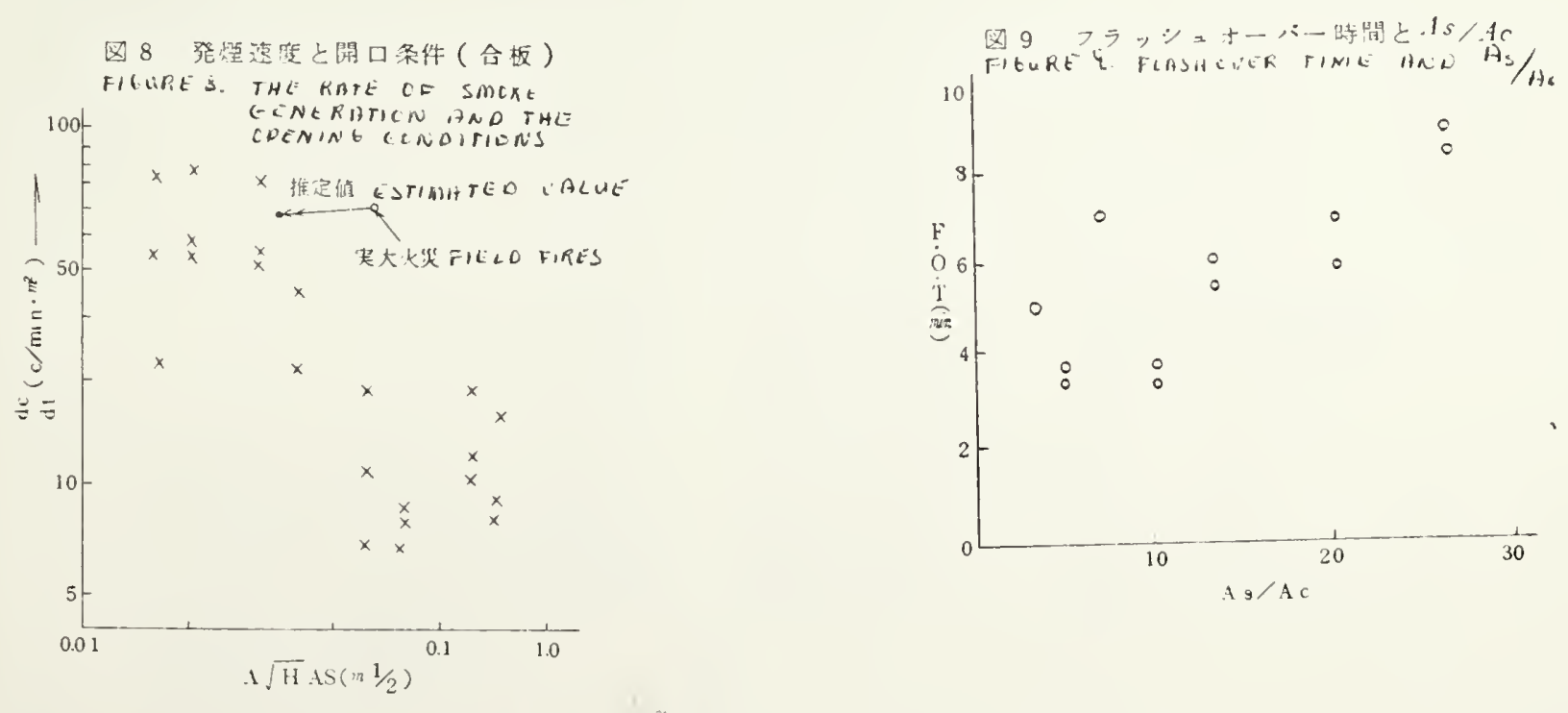
(iv) Flashover Time and Fire Source

Flashover starts when the concentration of combustible gases in the fire room gets into a certain range. Consequently, the time taken from ignition up to flashover depends upon the opening condition and size of the fire source. For a given opening condition, flashover is determined by the rate of heating acting on the materials (size of fire source)。Figure 9 shows a plot flashover time against A / A for plywood. For the case of cribs experiment, it requires the correction for the time taken to active burning of the fire source. An empirical equation for plywood at the opening ratio of $1 / 4$ is obtained as follows:

$$
\text { F. O.T. }=\left[2.6+0.3\left(\frac{A_{S}}{A_{C}}\right)\right]-D
$$

Here $\mathrm{D}$ is the time taken to develop into a certain degree of fire. 
THBLI 3 EXPERIMENTAL RESULTS

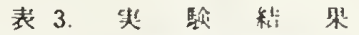

\begin{tabular}{|c|c|c|c|c|c|c|c|c|c|c|c|c|c|c|}
\hline \multirow{2}{*}{ 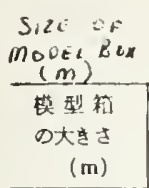 } & \multirow[b]{2}{*}{ 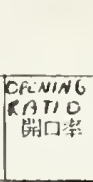 } & \multirow{2}{*}{$(\mathrm{nl} / 2)$} & \multicolumn{2}{|c|}{ 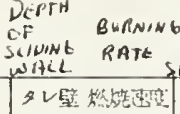 } & \multicolumn{4}{|c|}{ 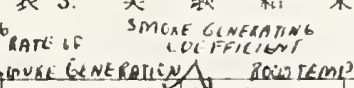 } & \multicolumn{2}{|c|}{$\begin{array}{l}\text { Flash } \\
\text { Clisen } \\
\text { RME }\end{array}$} & \multicolumn{3}{|c|}{ THWICNEESS } & \multirow[b]{2}{*}{ 侻 } \\
\hline & & & 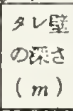 & $\begin{array}{r}\left(h_{2} \text { inin }\right. \\
\left./ \mathrm{m}^{2}\right)\end{array}$ & 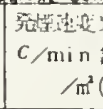 & (1) $\times()^{2}$ & 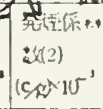 & 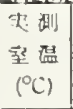 & $\begin{array}{l}\text { フォ } \\
\text { t- } \\
\text { 時 }\end{array}$ & 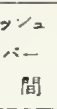 & As/de & $\left\{\begin{array}{c}i \\
t j i+4\end{array}\right.$ & $\begin{array}{l}67 \\
(m m)\end{array}$ & \\
\hline \multirow[t]{7}{*}{$1 \times 2 \times 1$} & $1 / 2$ & 0.142 & 0 & 0.97 & - & - & - & 800 & & $00^{\prime \prime}$ & 18.9 & 合 枚 & 5.5 & \\
\hline & $1 / 3$ & 0.110 & 0 & 0.82 & - & - & - & 865 & & $30^{\prime \prime}$ & 198 & $\pi$ & & \\
\hline & $1 / 4$ & 0065 & 0 & 087 & - & - & - & 895 & & $20^{\prime \prime}$ & 204 & Porwites & ?. & \\
\hline & , & , & 0 & 069 & - & - & - & 900 & $8^{\prime} 3$ & $30^{\prime \prime}$ & 123 & $\downarrow$ & - & \\
\hline & $1 / 8$ & 0.032 & 0 & 0.66 & - & - & - & 740 & $10^{\prime 3}$ & $30^{\prime \prime}$ & 211 & 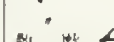 & $\cdot$ & \\
\hline & $1 / 4$ & 0.065 & 0 & 102 & - & - & -- & 870 & $6^{\prime}$ & $40^{\prime \prime}$ & 12.3 & 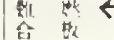 & 4 & PIYW:- \\
\hline & $\cdot$ & " & 0 & 100 & - &.- & - & 885 & $9^{\prime} 4$ & $40^{\circ}$ & $20: 1$ & ti, th & , & 悀部 5.2 \% \\
\hline \multirow[t]{17}{*}{$09 \times 18 \times 09$} & $1 / 3$ & 0090 & 0 & 101 & 286 & 17 & $2 \times .3$ & 850 & $7^{\prime}+$ & $+5^{\prime \prime}$ & 10.6 & $\hat{f}_{i} \nabla_{i}$ & 5.5 & MUSTURE \\
\hline & $1 / 4$ & 0.065 & 0 & 088 & 25.7 & 25 & 28.2 & 830 & $6^{\prime} 5$ & $50^{\prime \prime}$ & 10.9 & Pryide & o. & "ENIENT \\
\hline & $1 / 8$ & 0.031 & 0 & 0.69 & 12.7 & 16 & 18.1 & 700 & $6^{\prime}$ & $25^{\prime \prime}$ & 113 & . & ‘ & - \\
\hline & $1 / 3$ & 0090 & 0 & 088 & 37.0 & 44 & 42.05 & 650 & $10^{\prime} \mathrm{C}$ & $00^{\prime \prime}$ & 10.6 & - & 9.0 & \\
\hline & $1 / 4$ & 0.065 & 0 & 0.75 & 488 & 66 & 65.1 & 870 & $8^{\prime} 1$ & $00^{\prime \prime}$ & 10.9 & . & - & \\
\hline & $1 / 8$ & 0.031 & 0 & 0.55 & 462 & 37 & $84 \Omega$ & 800 & $7^{\prime} 1$ & $00^{\prime \prime}$ & 113 & , & . & \\
\hline & $1 / 3$ & 0.090 & 0 & 0.79 & 22.0 & 36 & 2785 & 850 & $7^{\prime}$ & $40^{\prime \prime}$ & 10.6 & , & 12.0 & \\
\hline & $1 / 4$ & 0065 & 0 & 0.81 & 26.7 & 35 & 330 & 900 & $7^{\prime} 2$ & $25^{\prime \prime}$ & 109 & - & , & \\
\hline & $1 / 8$ & 0031 & 0 & 0.71 & 17.5 & 25 & 2465 & 860 & $6^{\prime} 3$ & $30^{\prime \prime}$ & 113 & " & 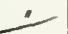 & TREATEO AIFOA \\
\hline & $1 / 3$ & 0090 & 0 & 0.66 & 246 & 36 & 373 & 720 & $11^{\prime} 4$ & $40^{\prime \prime}$ & 10.6 & 媓 & 5.5 & 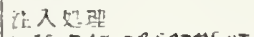 \\
\hline & $1 / 4$ & 0065 & 0 & 0.69 & 358 & 79 & 519 & 650 & $11^{\prime} 1$ & $15^{\prime \prime}$ & 10.9 & s. & . & INUEC TIGA TREATMENT \\
\hline & $1 / 8$ & 0.031 & 0 & 0.66 & 29.5 & 68 & 44.7 & 600 & $10^{\prime} \mathrm{C}$ & $00^{\prime \prime}$ & 113 & - & " & \\
\hline & $1 / 4$ & 0065 & 0 & 0.78 & 86.5 & 135 & 1109 & 750 & $8^{\prime} 3$ & $35^{\prime \prime}$ & 109 & ' & " & 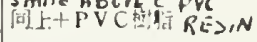 \\
\hline & $1 / 8$ & 0031 & 0 & 0.56 & 1122 & 210 & 198.5 & 700 & $9^{\prime} \mathrm{C}$ & $0 u^{\prime \prime}$ & 113 & , & " & \\
\hline & $1 / 3$ & 0.090 & 0 & 0.65 & 39.8 & 63 & 6125 & 720 & $12^{\prime}$ & $40^{\prime \prime}$ & 106 & - & , & \\
\hline & $1 / 4$ & 0.065 & 0 & 0.71 & 46.0 & 65 & 6409 & 800 & $11^{\prime} 4$ & $45^{\prime \prime}$ & 10.9 & " & , & 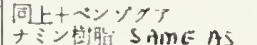 \\
\hline & $1 / 8$ & 0.031 & 0 & 034 & - & - & - & 650 & $10^{\prime}$ & $40^{\prime \prime}$ & 113 & fincis & , & AB:DE \\
\hline \multirow[t]{12}{*}{$0.5 \times 10 \times 0.5$} & $1 / 2$ & 0.127 & 0 & 0.47 & 10.08 & - & 22.5 & 600 & $6^{\prime} 3$ & $30^{\prime \prime}$ & 152 & 合 掫 & 5.5 & \\
\hline & $\cdot$ & , & 8 & 0.51 & 1248 & - & 24.4 & 650 & $5^{\prime} 3$ & $30^{\prime \prime}$ & , & n & ' & \\
\hline & , & , & 16 & 0.48 & 1920 & - & 40.0 & 730 & $6^{\prime} 4$ & $47^{\prime \prime}$ & , & - & " & \\
\hline & $1 / 4$ & 0063 & 0 & 0.52 & 1056 & 34 & 20.4 & 670 & $6^{\prime} 3$ & $30^{\prime \prime}$ & 163 & " & - & \\
\hline & , & , & 8 & 0.52 & 624 & 13 & - & 680 & $6^{\prime} 2$ & $27^{\prime \prime}$ & . & . & " & \\
\hline & , & , & 16 & 0.57 & 1728 & 50 & 303 & 650 & $6^{\prime} 3$ & $30^{\prime \prime}$ & . & . & - & \\
\hline & $1 / 8$ & 0031 & 0 & 0.41 & 73.90 & 110 & 1800 & 680 & $6^{\prime}$ & $15^{\prime \prime}$ & 17.0 & . & - & \\
\hline & $\cdot$ & ' & 8 & 0.42 & 4240 & .113 & 106.0 & 670 & - & - & • & . & , & \\
\hline & ' & , & 16 & - & 42.72 & $\cdot-$ & $\ldots$ & 690 & - & - & , & . & . & \\
\hline & $1 / 16$ & 0016 & 0 & 023 & 73.14 & - & 314.0 & 600 & - & - & 173 & . & , & \\
\hline & $\cdot$ & , & 8 & 027 & 44.64 & - & 1652 & 615 & & - & , & . & - & \\
\hline & $\cdot$ & a & 16 & 026 & 23.04 & - & 889 & 650 & - & - & - & . & " & \\
\hline \multirow[t]{21}{*}{$0.5 \times 0.5 \times 1.0$} & $1 / 2$ & 0.150 & 0 & 0.63 & 1620 & - & 256 & 730 & & $15^{\prime \prime}$ & 17.4 & " & " & \\
\hline & , & , & 15 & 0.61 & 820 & - & 14.5 & 800 & & $40^{\prime \prime}$ & . & . & , & \\
\hline & $\cdot$ & , & 30 & 0.61 & 9.27 & - & 152 & 780 & $6^{\prime}=$ & $50^{\prime \prime}$ & , & " & . & \\
\hline & $1 / 4$ & 0079 & 0 & 0.65 & 6.08 & 13 & 10.7 & 800 & $6^{\prime}$ & $05^{\prime \prime}$ & 186 & . & . & \\
\hline & 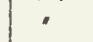 & , & 15 & 0.74 & 6.89 & 20 & 10.7 & 770 & $6^{\prime}$ & $35^{\prime \prime}$ & , & , & . & \\
\hline & , & , & 30 & 0.67 & 9.32 & 19 & 139 & 750 & $6^{\prime}$ & $00^{\prime \prime}$ & , & . & , & \\
\hline & $1 / 8$ & 0040 & 0 & 0.80 & 35.64 & 53 & 44.7 & 680 & $7^{\prime}$ & $25^{\prime \prime}$ & 193 & . & . & \\
\hline & , & , & 15 & 0.63 & 21.87 & 20 & 308 & 700 & & - & , & , & " & \\
\hline & , & ' & 30 & 0.41 & - & - & - & 570 & & - & , & - & - & \\
\hline & $1 / 16$ & 0.020 & 0 & 027 & 46.58 & - & 1712 & 580 & & - & 19.5 & " & * & \\
\hline & , & , & 15 & 034 & 48.20 & - & 141.7 & 560 & & - & , & " & , & \\
\hline & , & , & 30 & 034 & 80.60 & - & 237.0 & 560 & & - & , & 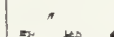 & $\dot{\sim}$ & TREATED \\
\hline & $1 / 2$ & 0150 & 0 & 032 & 55.8 & - & 174.0 & 330 & - & - & 52 & 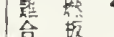 & $\mathcal{S}_{5.5}$ & PLvw:i.s \\
\hline & . & , & 15 & 0.51 & 55.8 & - & 1095 & 650 & $8^{\prime}$ & $40^{\prime \prime}$ & , & D. & , & \\
\hline & , & , & 30 & 0.51 & 68.8 & - & 135.0 & 700 & $10^{\prime}$ & $40^{\prime \prime}$ & . & " & , & \\
\hline & $1 / 4$ & 0.079 & 0 & 0.61 & 55.8 & - & 91.7 & 760 & & $50^{\prime \prime}$ & 5.5 & . & , & \\
\hline & , & , & 15 & 0.49 & 612 & - & 124.8 & 800 & $7^{\prime}$ & $35^{\prime \prime}$ & $n$ & , & , & \\
\hline & , & , & 30 & 0.54 & 84.3 & - & 156.5 & 770 & & $45^{\prime \prime}$ & . & - & . & \\
\hline & $1 / 8$ & 0.040 & 0 & 0.29 & 112.8 & - & 1912 & 700 & - & -. & 58 & , & ' & \\
\hline & ' & , & 15 & 054 & 55.8 & - & 1032 & 680 & & - & ' & ' & , & \\
\hline & , & , & 30 & 0.17 & 688 & - & 146.5 & 610 & & - & - & , & . & \\
\hline
\end{tabular}

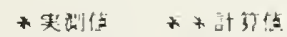

* experimental value

* predictio valle 
T. Wakamatsu

\section{Study Objectives}

The present experiment aims to determine the minimum amount of required air supply to prevent smoke entering the stair room for various opening conditions, and using the experimental results to compare with theoretical calculation (1)。

\section{Experimenta1 Insta1lations}

Air supply and smoke discharge passages, the stair rooms and the living rooms were installed on first to fifth floor of a five-story building. The fire room (the living room on the third floor served as the fire room in the present experiment) and air conditioning unit (whose supply capacity of $5 \mathrm{~m}^{3} /$ sec and conditioning capability ranging from $-10^{\circ} \mathrm{C}$ to $20^{\circ} \mathrm{C}$ with respect to the outside air) were set up on the first floor and the instrument room on the second floor. The air supply passage was connected to a blower through a duct, and a natural draft smoke opening and a suction fan (capacity $2.5 \mathrm{~m} /$ $\mathrm{sec}$ ) were installed at the roof portion of the smoke discharge passage. In order to make the position and the area of the openings adjustable, two ventilation openings which connected the living room to supply and discharge passages were dividea into six portions in vertical direction, and installed with six pieces of $1 \mathrm{~m}$ wide $\mathrm{x} 40 \mathrm{~cm}$ high door. 


\section{Experimental Procedure}

Alcohol contained in a pan with a cross-sectional area of $0.35 \mathrm{~m}^{2}$ was burned in the living room on the third floor and smoke was produced through a smoke generating cylinder. The tests were performed for 14 opening conditions in which doors D1, D2, and D3 on the first floor and door DF and window W1 of the fire room were always opened, and door DR of the stair room and window W2 of the fire room were either shut or opened. The size of each opening is presented in Table 1 。

表 1. iACKE\%。

\begin{tabular}{|c|c|c|c|c|}
\hline $\mathrm{D}_{1}$ & $\mathrm{D}_{2}, \mathrm{D}_{3}, \mathrm{DF}$ & DR & $W_{1}, W_{2}$ & 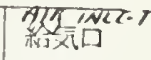 \\
\hline $1.64 \times 1.8$ & $0.82 \times 1.8$ & $0.82 \times 10$ & $0.56 \times 0.9$ & $0.5 \times 0.5$ \\
\hline
\end{tabular}

The amount of air supply was determined by hot wire anemometers placed at the center of each air entrance. In this case, the discharge coefficient for each opening was assumed to be 0.85 .

The ${ }_{3}$ experiment was started by running the blower at full capacity of about $5 \mathrm{~m}^{3} / \mathrm{sec}$, and setting fire to produce smoke in the fire room。 In this stage, most smoke would discharge out from the windows of the fire room. The mimimum amount of required air supply to the stair room was obtained by gradual reduction of air supply until the smoke started to move into the stair room. Repeated tests were made in duplicate or triplicate for each opening condition and a total of 31 runs was performed。

\section{Experimental Results and Observations (Comparison with the Calculated Values)}

Table 2 illustrates the average temperatures of air in the outdoor, the stair room and the fire room, the direction and the speed of the outside air measured at the instrument room, and the predicted and experimental values for minimum amount of required air supply. The predicted values were calculated based on the equations derived in Reference 1 along with the data obtained from the present experiment. In general, the predicted values are in reasonably good agreement with the experimental values.

\section{References}

[1] Wakamatsu, T。, "Calculation of Smoke Movement in Building," BRI Research Paper No。34, (1968)。 


\begin{tabular}{|c|c|c|c|c|c|c|c|c|c|}
\hline \multicolumn{10}{|c|}{ 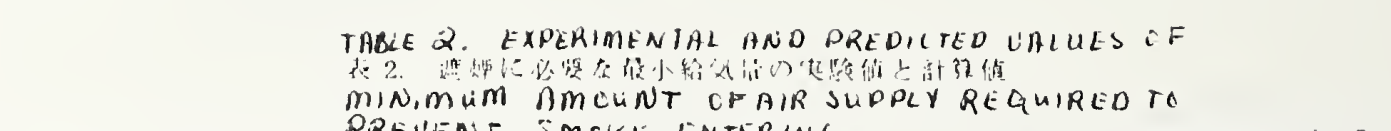 } \\
\hline \multirow{2}{*}{$\begin{array}{l}\text { SERIES } \\
\text { II } \\
\text { NOP. }\end{array}$} & \multicolumn{2}{|c|}{ 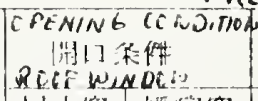 } & \multicolumn{2}{|c|}{ 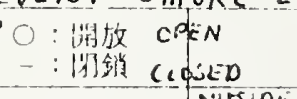 } & \multicolumn{2}{|c|}{ TEMPCiRnTURE } & \multicolumn{3}{|c|}{ 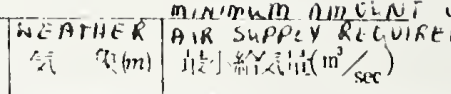 } \\
\hline & $\begin{array}{c}1, \frac{1}{1}+\frac{1}{2} \\
\mathrm{DR}\end{array}$ & $1+2$ & 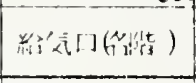 & $\begin{array}{l}\text { Ourside } \\
\text { 外 } 2 i \\
\text { Ain }\end{array}$ & 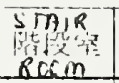 & $\begin{array}{l}\text { FIRE } \\
\text { KOK } \\
\text { ROEN }\end{array}$ & 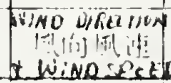 & 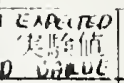 & 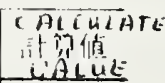 \\
\hline \multirow{2}{*}{$1-1$} & & \multirow{2}{*}{$\begin{array}{l}\text { Fincre } \\
\text { WiNDCing }\end{array}$} & \multirow[t]{2}{*}{ eim } & 18.0 & $1 \times 0$ & 50.0 & 0 & 12 & 1.3 \\
\hline & & & & 19.0 & 19.0 & 57.0 & 0 & 12 & \\
\hline \multirow{2}{*}{$1-2$} & \multirow{2}{*}{-} & \multirow{2}{*}{-} & \multirow{2}{*}{1} & 21.0 & 21.0 & +5.0 & So.2 & 1.5 & 12 \\
\hline & & & & 18.0 & 18.0 & 5.5 .0 & 0 & 1.4 & \\
\hline \multirow{3}{*}{$1-3$} & \multirow{3}{*}{ - } & \multirow{3}{*}{-} & \multirow{3}{*}{2,4} & 19.0 & 19.0 & 50.0 & $S_{2.0}$ & 1. 3 & 1.3 \\
\hline & & & & 21.0 & 21.0 & 59.0 & $N T W_{0.2}$ & 1.6 & \\
\hline & & & & 19.0 & 20.0 & 55.0 & $E 12$ & 1.5 & \\
\hline \multirow{2}{*}{$1-4$} & \multirow{2}{*}{--} & \multirow{2}{*}{ - } & \multirow{2}{*}{$1 \sim 5$} & 20.0 & 20.0 & 61.0 & E 1.5 & 1.6 & 1. 6 \\
\hline & & & & 17.0 & 17.0 & 55.0 & $\mathrm{E}_{1.2}$ & 1.6 & \\
\hline \multirow{3}{*}{$2-1$} & \multirow{3}{*}{ - } & \multirow{3}{*}{$\mathrm{O}$} & \multirow{3}{*}{5} & 18.0 & 18.0 & 53.0 & $\mathrm{SHV}_{1.2}$ & 0.8 & 1.2 \\
\hline & & & & 16.0 & 16.0 & 62.0 & $\mathrm{E}_{0.2}$ & 1. 1 & \\
\hline & & & & 17.0 & 18.0 & 50.0 & E 0.5 & 1.3 & \\
\hline \multirow{2}{*}{$2-2$} & - & 0 & ${ }_{1}$ & 17.0 & 17.0 & 4 6. 0 & $S W_{10}$ & 1.1 & 1.0 \\
\hline & - & $U$ & 1 & 16.0 & 16.0 & 45.0 & E 1.0 & 1.3 & \\
\hline & & & & 20.0 & 20.0 & 52.0 & 112.0 & 1. 2 & 1. 2 \\
\hline $2-3$ & - & C & 2,4 & 20.0 & 20.0 & .32 .0 & 0 & 1.3 & \\
\hline & & & & 20.0 & 20.0 & 50.0 & $E 0.2$ & 1.1 & \\
\hline $2-4$ & .- & 5 & $i \sim 5$ & 16.0 & 1 6. 0 & 54.0 & $\mathrm{E} 0.3$ & 1.0 & 1.3 \\
\hline$z=4$ & 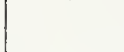 & & $1-0$ & 15.0 & 15.0 & +5.0 & SSII 1.5 & 10 & \\
\hline & - & 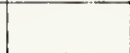 & & $16.1)$ & 16.0 & 1.0 & E 10 & 2.5 & 2.0 \\
\hline 1 & 3 & & 1 & 18.0 & 18.0 & 520 & E 1.5 & 2.5 & \\
\hline 2 & 0 & 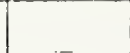 & 2 & 19.0 & 19.0 & 16.0 & II: 20 & 2.2 & 2.2 \\
\hline $3-2$ & 1 & 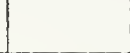 & 2,4 & 18.0 & 18.0 & 53.0 & 0 & 2.2 & \\
\hline $3-3$ & 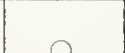 & - & $1 \sim 5$ & 15.0 & 15.0 & 58.0 & E (1.2 & 2.1 & 2.5 \\
\hline $3-3$ & -1 & 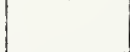 & $1>0$ & 15.0 & 15.0 & 52.0 & $E 0.1$ & 2.6 & \\
\hline & & 1) & & 18.0 & 18.0 & 34.0 & $E: 0$ & 17 & \\
\hline $1-1$ & $\because$ & 3 & 1 & 18.0 & 18.0 & 17.11 & $E_{1.5}$ & 1.7 & 1.2 \\
\hline $1 \quad 0$ & 1) & 1) & 2 & 19.0 & 19.0 & $1: 0$ & 1120 & 1.8 & 1.1 \\
\hline $1=$ & C & ( & $2,+7$ & 19.0 & 19.0 & 13.0 & $N 0.8$ & 1.7 & \\
\hline & & i) & & 18.0 & 19.0 & 63.0 & $\mathrm{SW}_{2} .0$ & 1.4 & \\
\hline $1-3$ & () & (-) & $1 \sim 5$ & 18.0 & 18.0 & 60.0 & $S W_{1.2}$ & 2.2 & 1.9 \\
\hline
\end{tabular}




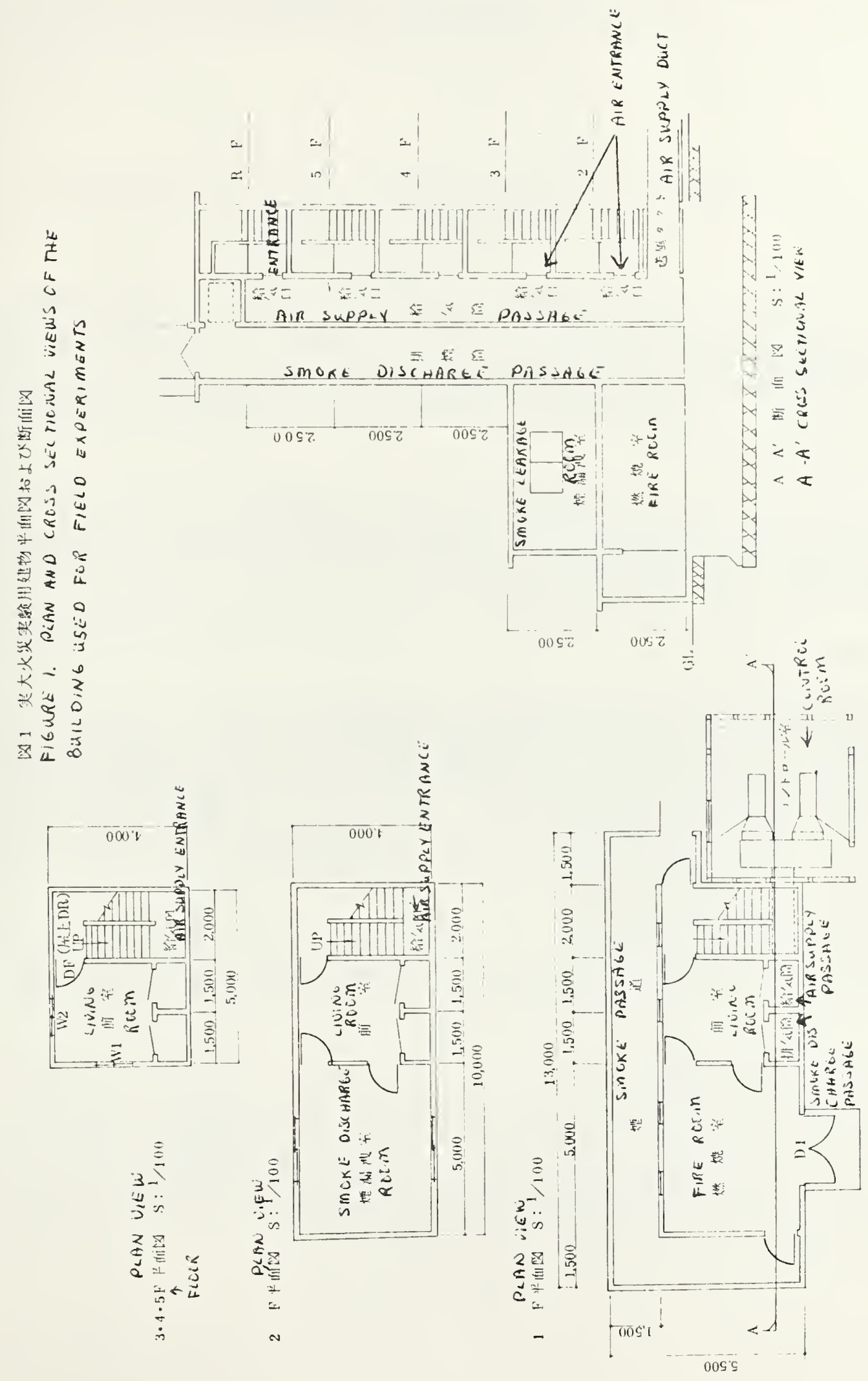




\title{
FIELD FIRE EXPERIMENTS FOR INTERIOR \\ FINISH MATERIALS
}

\author{
by \\ F。 Saito \\ From "Industrial Materials", Vol. 16, No。13, pp 104-112
}

\section{Introduction}

In spite of a building constructed entirely from non-combustible materials, it still possesses a high degree of the potential of fire hazard because of the combustibilities of furniture and goods within the building. Several fire experiments were sponsored by the Building Research Institute in which the following four experiments were related to interior finish materials.

\section{Experimenta1 Procedure}

The accuracy and the repeatability of the experiments on field fires are decreased with an increase in size of the building. However, the experimental procedure and the ignition method were carried out in the same manner for each run.

\section{Ignition Method}

Wood cribs, which were constructed of 12 pieces of $2 \mathrm{~cm} \times 2 \mathrm{~cm} \mathrm{x} 60 \mathrm{~cm}$ spruce sticks per layer, were placed at the corner of a compartment and were ignited by inserting an alcohol soaked stick $(1 \mathrm{~cm} \times 1 \mathrm{~cm} \times 60 \mathrm{~cm})$ at the bottom layer. Wood cribs which were piled up to 10 layers and located near the center of the room were used as the fire source to simulate office fires in the fire experiments made in May 1967, and cribs piled up to 31 layers were employed for the experiments in April 1968.

\section{Temperature Measurements}

Temperature measurement was made with CA thermocouples (Class 0.65 ) connected to the electronic type self-balancing temperature recorders.

\section{Smoke Concentration}

The attenuation coefficient is used in the present experiment for the indication of smoke density. The conventional way to measure the smoke concentration is direct measurement of the intensity of light attenuated by the smoke between the light source and the receiver, but this method has limitations due to the temperature compensation of the cell and the effect of flame present in the smoke in some cases. 
A temperature compensation type sucking smoke meter was employed for measuring smoke concentration。(See sketch)

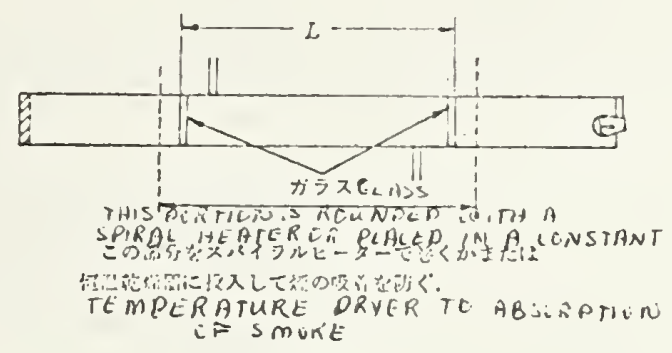

\section{Gas Analysis}

In gas analysis, $\mathrm{CO}_{2}$ and $\mathrm{O}_{2}$ were separately determined for the experiments in 1964, $\mathrm{CO}$ gas in 1965, and $\mathrm{CO}, \mathrm{CO}_{2}$ and $\mathrm{O}_{2}$ gases were analyzed in the 1967 experiments。

\section{Kinds of Interior Finish Materials and Flashover}

Flame spread, the temperature and duration of fire depend on the kinds and amount of combustible loads such as the materials used as walls and ceilings, and air ventilation conditions. Table 1 shows several field experiments in which actual building materials were employed and some of the observations are added as follows:

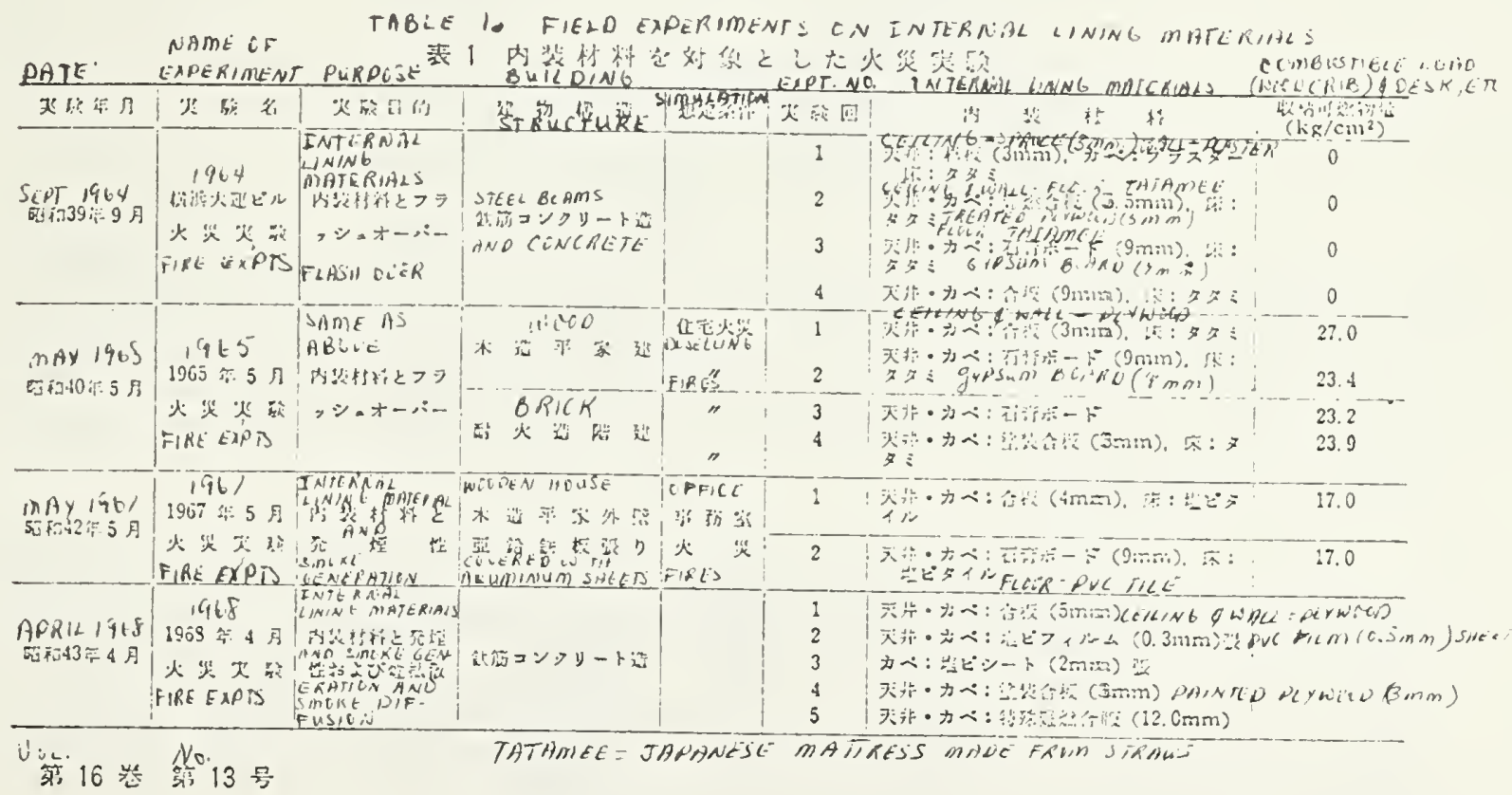




\section{Combustibility of Internal Lining Material}

As shown in Table 1, the experiments were carried out under such conditions that with the exception of one room, the remaining three rooms were 1 ined with the same sort of materials for walls and ceilings。

In this case, the materials used have the following relation with the classification of building materials designated by the regulation:

Partially non-combustible material: gypsum board Hardly combustible material: treated plywood Combustible material: plywood

The material which is classified above the hardly combustible material is considered as a fire resistant material. Figure 1 shows that the difference in the time taken to flashover between plywood and treated plywood was about 1.5 minutes. However, this deviation in flashover time is dependent upon the size of fire source and the compartment size.

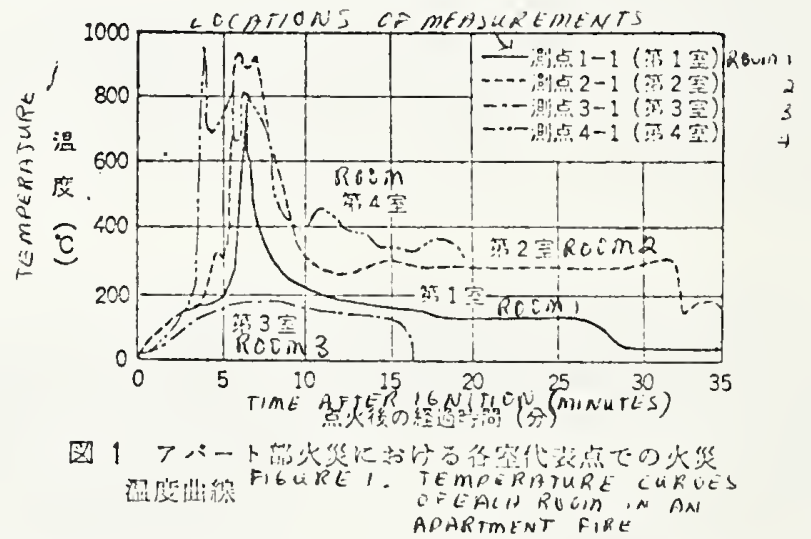

The interior finish material used in the third room was a partially noncombustible material and only burned the paper coated on the surface of gypsum board located around the fire source. The walls of the first room were internally finished respectively with non-combustible materials and Japanese cedar, and the fire source was located in the vicinity of cabinets within the compartment.

The rate of smoke generation at flashover and the flashover time for several interior finish materials used in model and field experiments are summarized in Table 2. The flashover time as described before is dependent upon the ratio of the size of fire source (the rate of heat release) and the exposed surface area inside the compartment and the comparison is not possible as the ratio is not fixed. However, the rate of smoke generation which depends on the smoke generating coefficient, the rate of thermal decomposition and the temperature can be used for comparison purpose。 
蒜 2 TARL 久

\begin{tabular}{|c|c|c|c|c|c|c|c|c|c|c|c|c|}
\hline \multirow{5}{*}{ 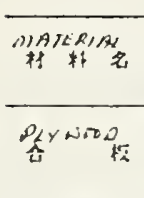 } & \multicolumn{4}{|c|}{$(0.45 \times 0.9 \times 0.45 \mathrm{~m})$} & \multicolumn{4}{|c|}{$(1.0 \times 2.0 \times 1.0 \mathrm{~m})$} & \multicolumn{3}{|c|}{$(5.0 \times 5.0 \times 3.3$} & \multirow{2}{*}{ 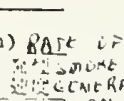 } \\
\hline & 572 & 80 & FOT & 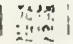 & rin & $\operatorname{lig}_{x \rightarrow \infty}:$ & FOT! & 30 & $\overrightarrow{\alpha i k} ;$ & .... & FOT! & \\
\hline & THES & 1913 & -1 & - & THEX. & a $8 x+3$ & $7 \cdot 45^{2}$ & 0.322 & TWES & कीज & & \\
\hline & 5.5 & $1 / 4$ & $5^{\prime}()^{\prime}$ & 0.405 & 5.5 & $1 / 1$ & 6.200. & 0.299 & 5.0 & $1 / 4$ & $f^{\prime} 30^{\circ}$ & 1.1 \\
\hline & & $1 / 8$ & $3.30 \%$ & 0.1 & & $1 / \mathrm{s}$ & & 0.237 & & & & \\
\hline TREATEDD & 5.5 & $1 / 4$ & $5^{\prime} 40^{\circ}$ & 0.37 & 5.5 & $\begin{array}{l}1 / 3 \\
1 / 4 \\
1 / 8\end{array}$ & $\begin{array}{l}11 \cdot 30^{\circ} \\
11155^{\circ} \\
: 0^{\circ} \mathrm{co}^{\circ}\end{array}$ & $\begin{array}{l}0.28: \\
0.114 \\
0.314\end{array}$ & 12.0 & $1 / 4$ & $8^{\prime} 30^{\circ}$ & 0.64 \\
\hline 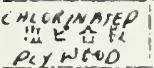 & & & & & 5.5 & $\begin{array}{l}1 / 4 \\
: / 8\end{array}$ & & $\begin{array}{l}1.00 \\
1.31\end{array}$ & 3.0 & $1 / 4$ & $5^{\prime} 30^{\circ}$ & 1.57 \\
\hline 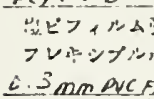 & $\begin{array}{l}v_{F}^{n} \\
\therefore-s^{4}\end{array}$ & 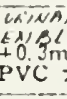 & 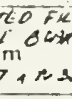 & $\operatorname{lm}_{10} 6 N$ & & & & & & $1 / 4$ & $3 \cdot 39$ & \\
\hline 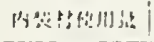 & & $\because 1$ & Om: & & & $=7$. & $5 \mathrm{~m}^{2}$ & & & & $2 m^{2}$ & \\
\hline
\end{tabular}

The experimental values obtained in model studies are less than those in the field experiment. This may be attributed to the low temperature and smoldering occurred in the field fires because through such a distance of about 40 to $50 \mathrm{~m}$ between outside air and the fire room, air supply for combustion is insufficient.

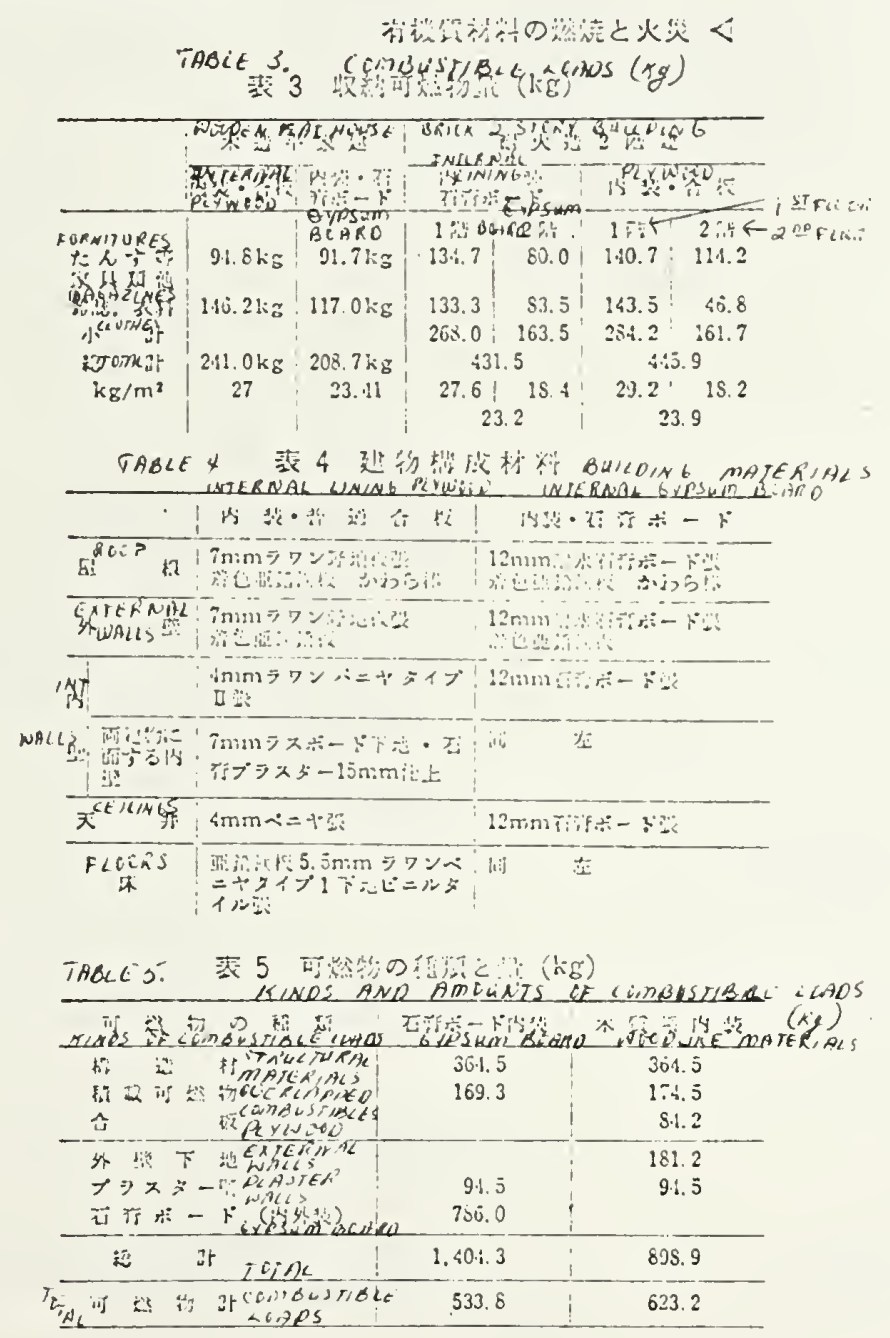




\section{For the Case of Combustible Loads Present in the Compartment}

Flashover is also dependent upon the amount of combustible loads present in the compartment. Especially for the case of dwellings, a large amount of various shapes of combustible materials in general scatters inside the compartment. The progress of fire is controlled by its intensity when the fire spreads over the surfaces of combustible loads such as furnitures. Thus, the time taken to flashover is dependent on the quantity of combustible load and types of construction materials used. The combustibilities of the materials employed greatly affect flashover and as shown in Figures 2 and 3, the degree of deflection for various building materials exposed to fires is noticeably different.

The experiments conducted to simulate office fires in May 1967 aimed to study the relation between smoke generation and internal lining materials. The size of the office used in these experiments was about $10 \mathrm{~m}^{2}$ and the fires were started by burning wood cribs placed near to a desk and a chair. A remarkable difference in gas composition and concentration of the smoke discharged from the openings of the building was observed as shown in Figures 4 to 6 for using various interior finish materials in spite of insignificant difference in their flashover times (see Figure 7)。

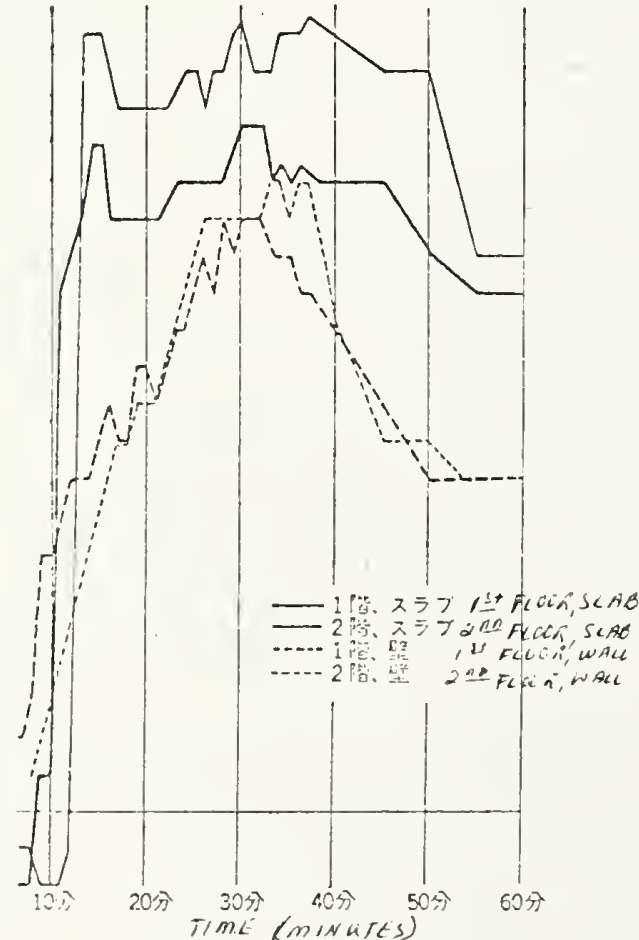

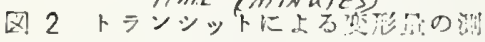

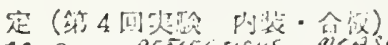

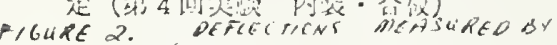
TRANSIIS (TEST AIO INTERNA UNIAIGS, PLY Y RTOS

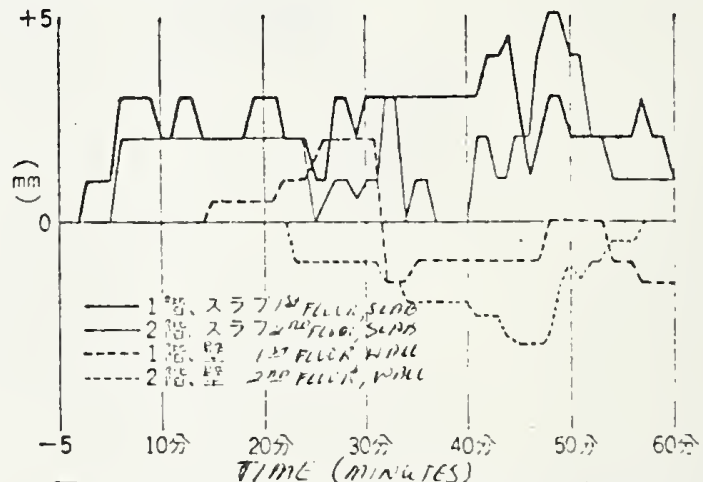

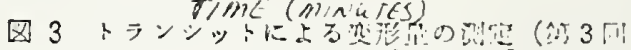

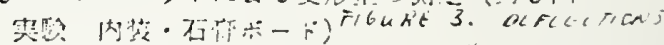

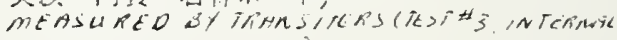

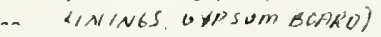

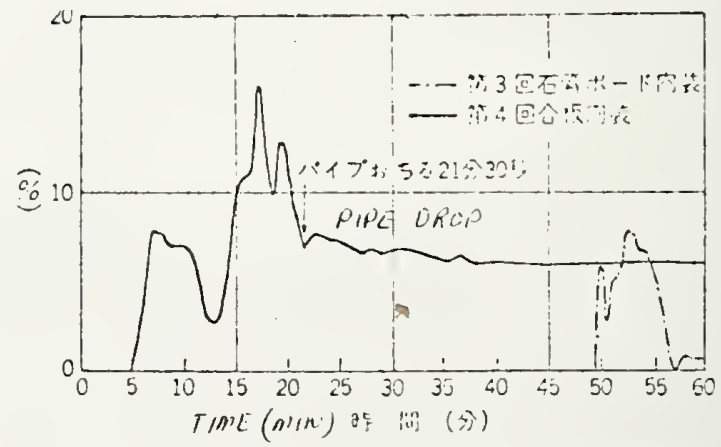

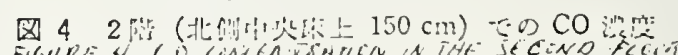

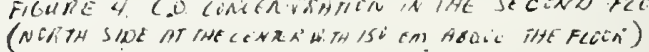




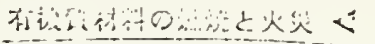
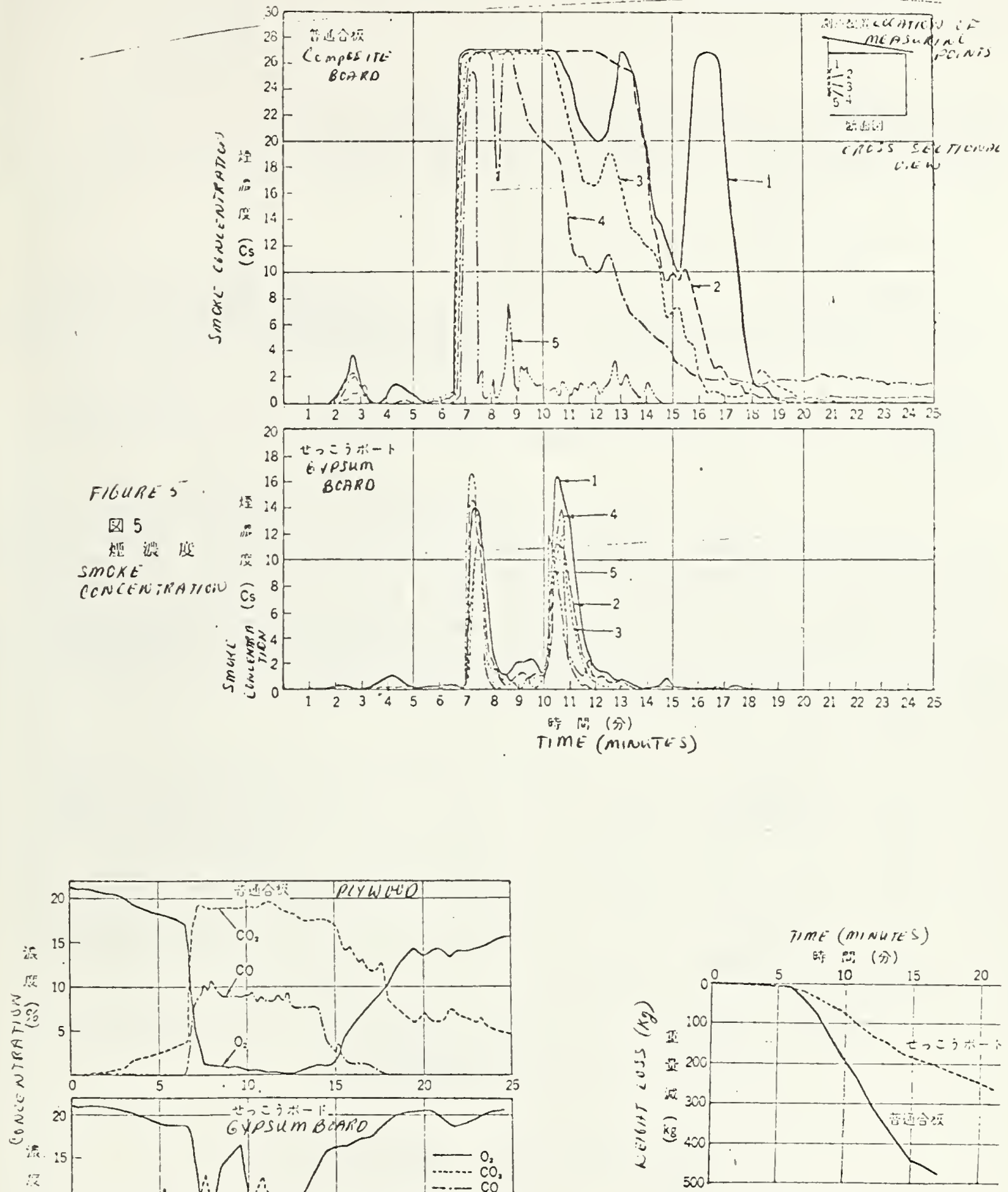

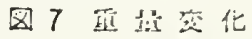

Flocike 7 witout cas

c IIPAigl 
Fire Experiments and Internal Lining Materials

From the experiments performed, it can be concluded that free burning fires and combustibility of the material have the following relations:

\section{No Combustible Materials in the Fire Room}

The flashover time for the case of internal lining materials only existing in the fire room depends upon the combustibility of the material involved, and the ratio of the burning rate of fire source to the exposed surface area of the interior finish materials. According to the classification of fire resistant materials, the material classified above as the partially noncombustible material shows almost no flashover, and a hardly combustible material simply prolongs the flashover time compared with the combustible material.

In the 1968 experiments, the smoke was discharged to the corridor from one side of the compartment, and these discharge rates and diffusion rates inside the building were determined. Figures 8 to 17 show details of the experiments and the rate of smoke generation for various kinds of materials. In the second experiment a PVC flexible board, the total amount of smoke produced tended to be flat when the fire became intensive as shown in Figure 17. Plywood and treated plywood used in No。's 1 and 4 experiments were completely burned out within 4 to 5 minutes after flashover.

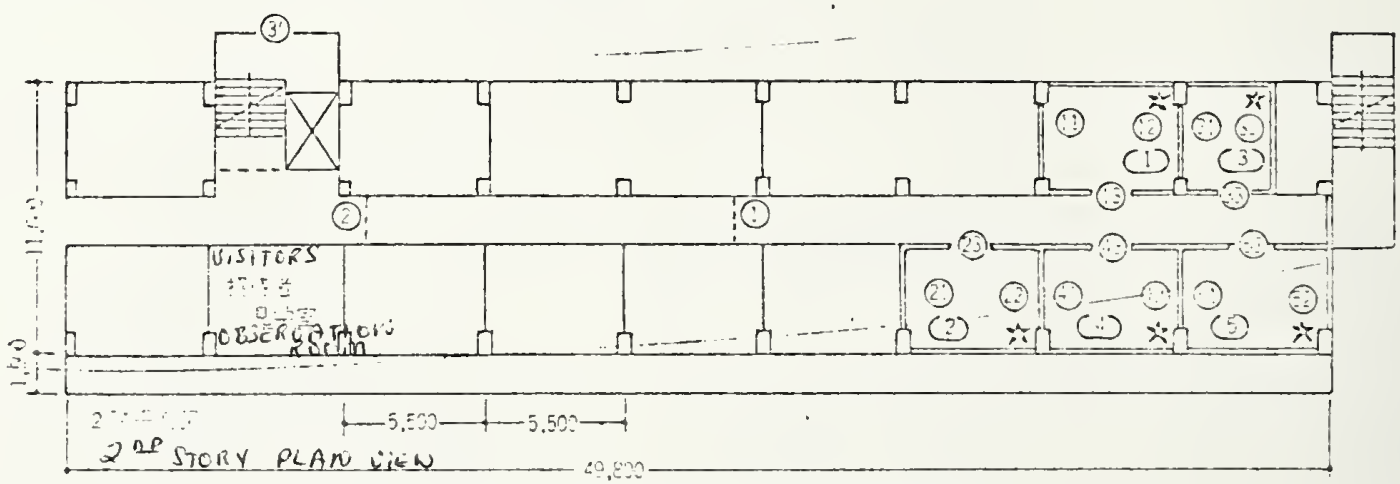

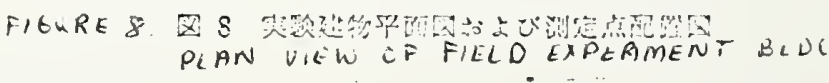

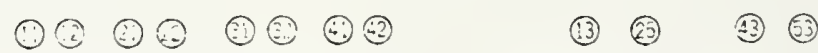

(TiSTS NC:
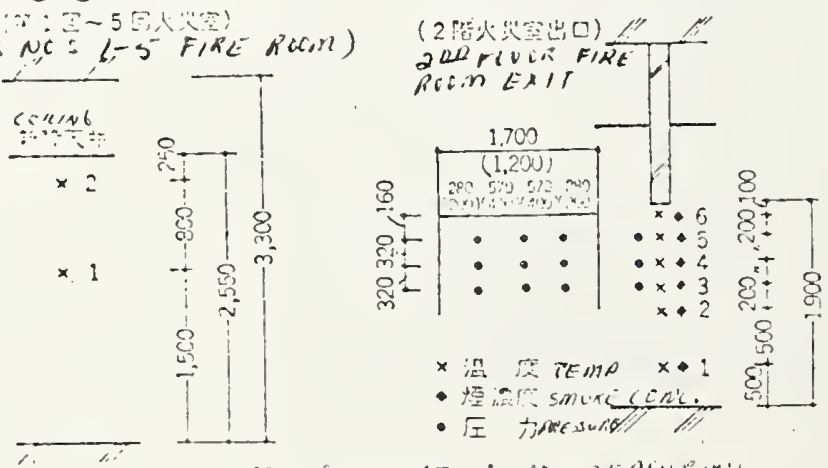

FIGURE \& COCATCN DF MITASURING

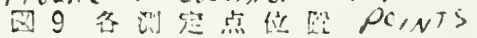




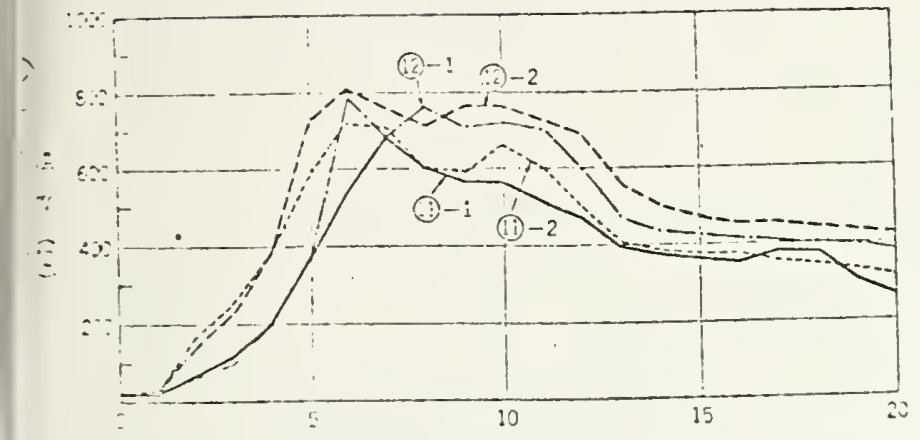

$\because$ in (3i)

$\operatorname{TimL}$ (minutss)

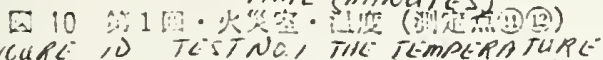

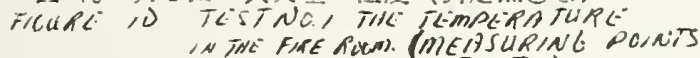
(11) (12)

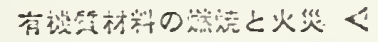

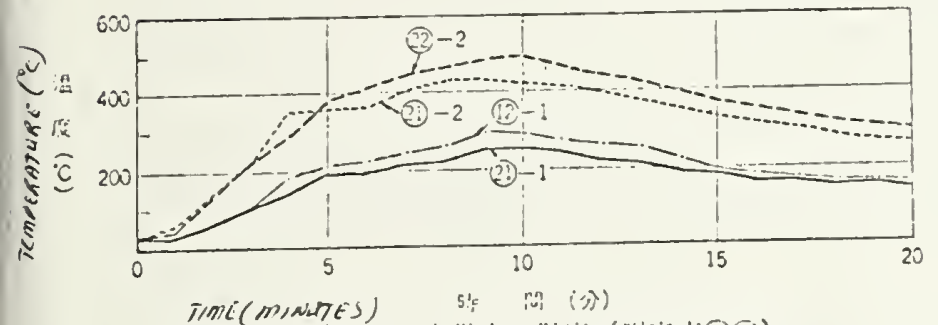

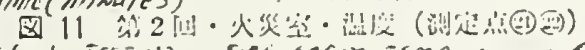

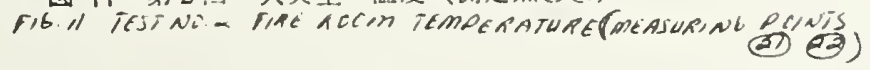

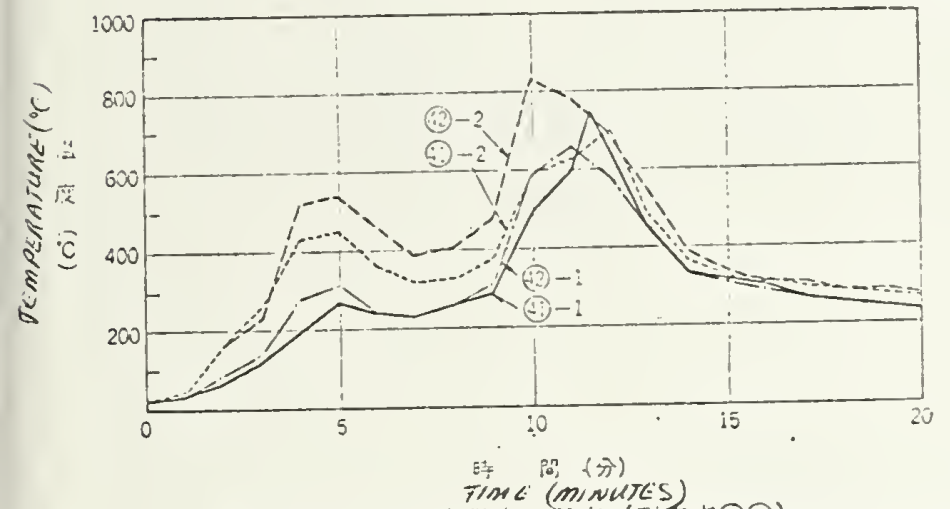

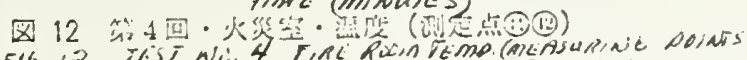

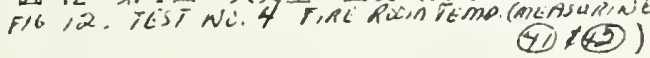

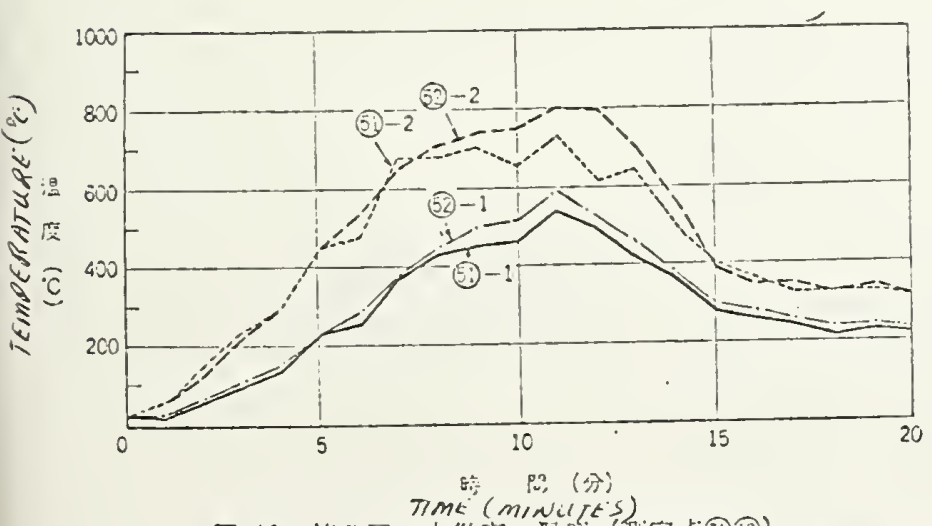

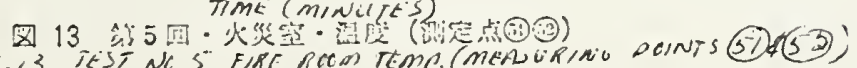

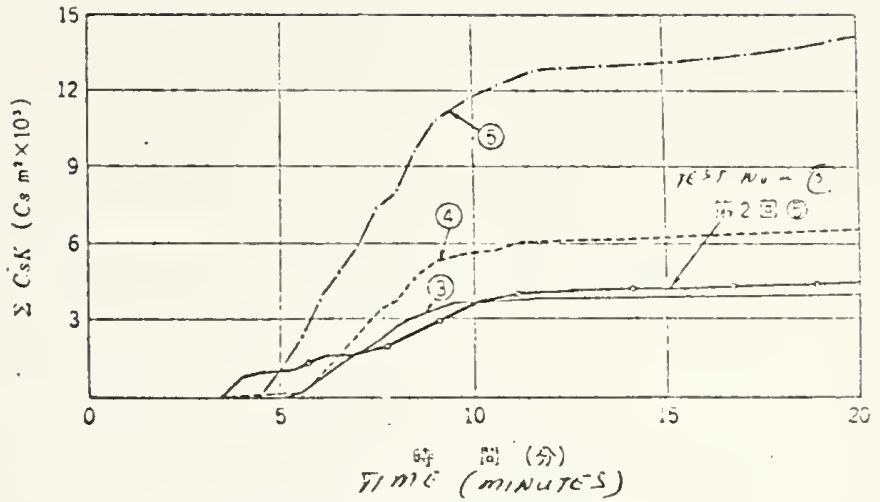

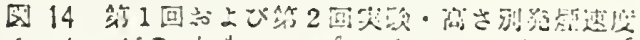

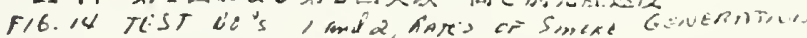
AT DIFFERUT MEIGITS 


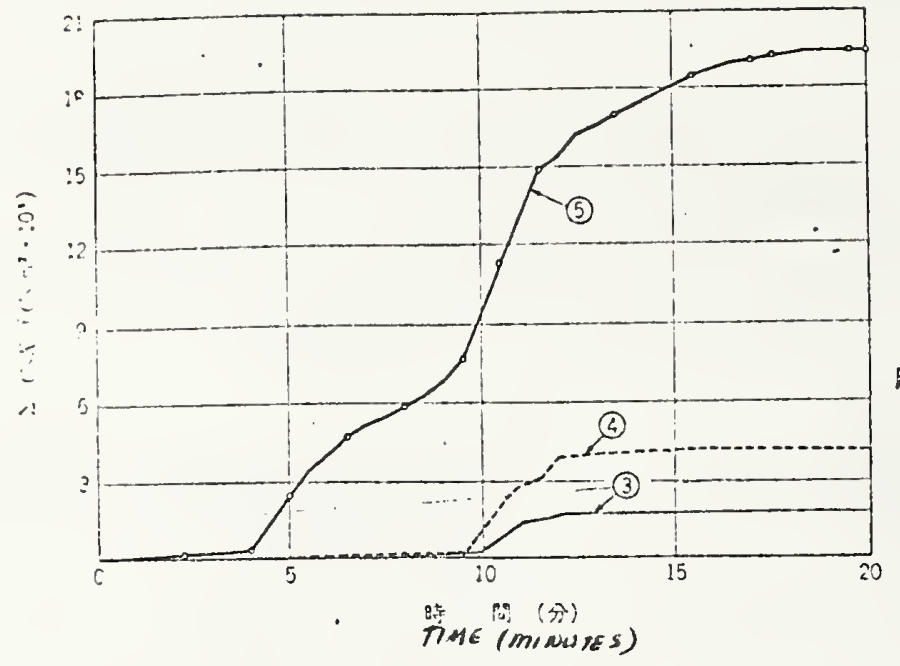

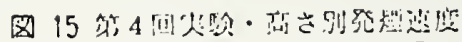
516.13 TLST NL. 7 , FATE if SMATE GENURATION AT OIFFERENT HEIGHTS

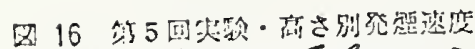
F/6.16. - TEST NO.S, RATE OF SMCKE GENERATION AT DIF. FERENT HEIGHTS
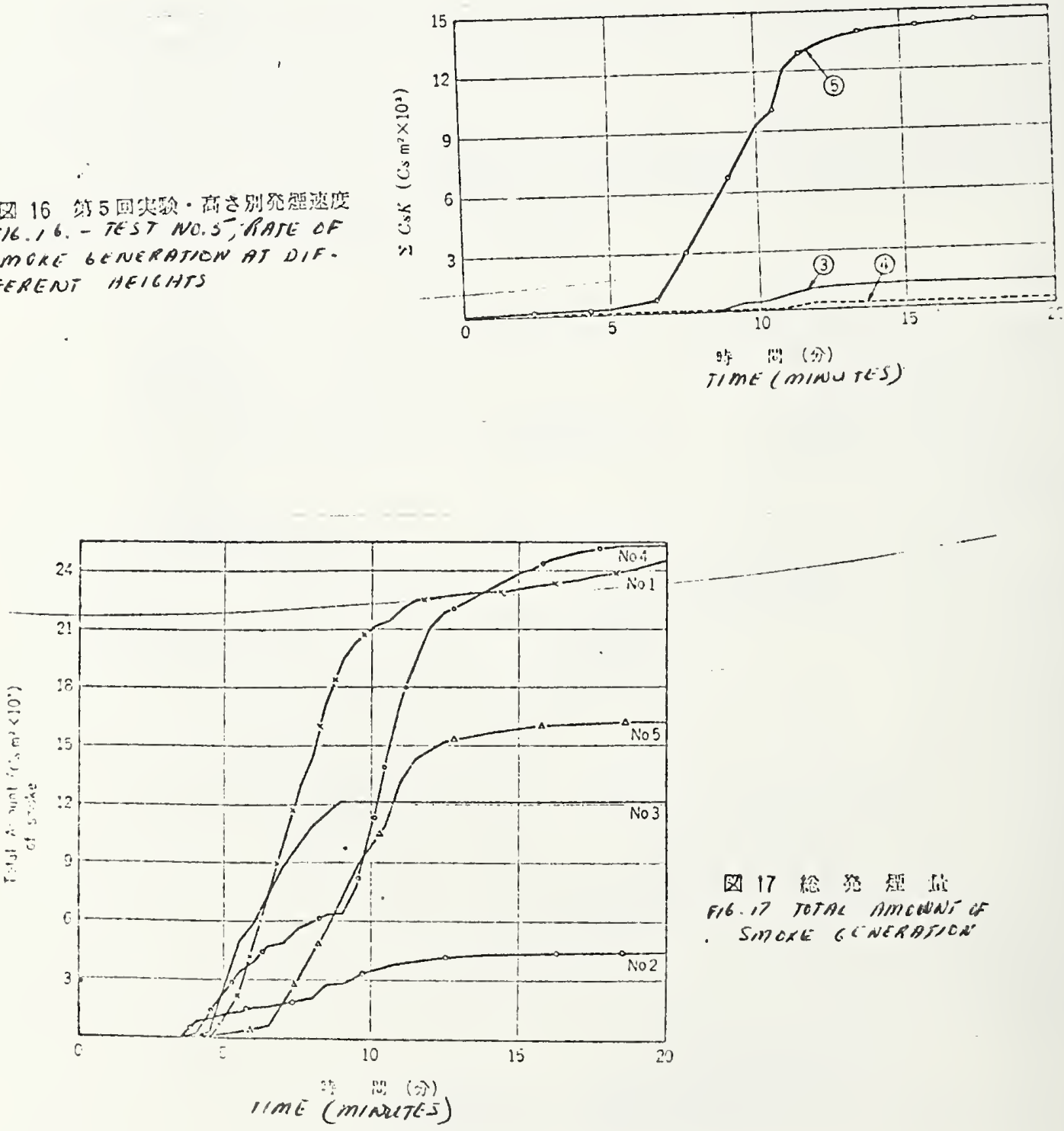

图 17 䜌恣照 Ii 616.17 TOTAL AMCUNS if - SMOXE G CNEROSIOA 


\section{A Large Amount of Combustible Loads in the Fire Room}

The fire experiments in 1965 were conducted on dwellings and the fire was initiated in front of the cabinets. In 1967, the experiments were directed towards the study of office fires and the fire started at the side of a desk. Under both conditions, the time taken to flashover was independent of the position of initiation of the fire and the properties of the materials used since the combustible materials were completely burned out beforehand. Consequently, the internal lining materials which are non-combustible can be expected to have the same results.

The interior finish materials which act as fuels in fires have a tremendous effect on the deflection of the building components. In the present experiment fire was initiated in the neighborhood of the cabinet where the combustibilities of the materials were difficult to compare. If the fires start at the opposite corner where the comparison of material characteristics is possible, a phenomena of no combustible loads in the fire room can be expected to be present. It can be concluded that the experiments on office fires in 1967 are similar to this case. 


